\title{
Fourth report of the Committee for Ecuadorian Records in Ornithology (CERO) and a revision of undocumented and erroneous records in the literature
}

\author{
Juan F. Freile ${ }^{1,2, *}$, Alejandro Solano-Ugalde ${ }^{1,3}$, Dušan M. Brinkhuizen ${ }^{1,4}$, Paul J. Greenfield ${ }^{1,5}$, Mitch Lysinger ${ }^{1,6}$, \\ Jonas Nilsson ${ }^{1,7}$, Lelis Navarrete ${ }^{1}$, Robert S. Ridgely ${ }^{1,8}$ \\ ${ }^{1}$ Comité Ecuatoriano de Registros Ornitológicos (CERO). \\ ${ }^{2}$ Red Aves Ecuador, Pasaje El Moro E4-216 y Norberto Salazar, Tumbaco. \\ ${ }^{3}$ Fundación Imaymana, Paltapamba 476, San Pedro del Valle, Nayón. \\ ${ }^{4}$ Rockjumper Birding Tours, Casilla Postal 17-07-9345, Quito. \\ ${ }^{5}$ Mindo Cloudforest Foundation, Urb. El Bosque, 2da Etapa, calle Sexta \#161, edif. El Parque, Quito. \\ ${ }^{6}$ Cabañas San Isidro, avenida Siena 318 y calle A, edif. MDX, of. 310, Cumbayá. \\ ${ }^{7}$ Wildsumaco Lodge, Leonardo da Vinci 239 y Rafael Sanzio, edif. Oberer, Cumbayá. \\ ${ }^{8}$ Rainforest Trust, 7078 Airlie Road, Warrenton, VA 20187. \\ *Autor para correspondencia/Corresponding author, e-mail: cero.ecuador@gmail.com \\ Editado por/Edited by: Harold F. Greeney \\ Recibido/Received: 12 October 2018 Aceptado/Accepted: 6 July 2019 \\ Publicado en línea/Published online: 31 December 2019
}

\section{Cuarto reporte del Comité Ecuatoriano de Registros Ornitológicos (CERO) y una revisión de registros indocumentados o erróneos en la literatura}

\section{Resumen}

Presentamos nuevos registros de distribución de aves del Ecuador que han sido enviados al Comité Ecuatoriano de Registros Ornitológicos (CERO) entre septiembre 2015 y julio 2017. Incluimos reportes de cuatro especies nuevas para Ecuador (Plegadis ridgwayi, Cathartes burrovianus, Malacoptila mystacalis, Vireo gilvus), dos especies nuevas para Galápagos (Calidris pugnax, Larosterna inca), cinco especies con primera documentación en Ecuador (Fregata minor, Syrigma sibilatrix, Calidris pugnax, Larus belcheri, Sternula antillarum), extensiones considerables de distribución de ocho especies (Anas bahamensis, Fregata sp., Jabiru mycteria, Phimosus infuscatus, Caracara cheriway, Larus dominicanus, Chloroceryle aenea, Sturnella militaris), nuevos reportes de ocho especies raras (Anhima cornuta, Mustelirallus albicollis, Larus argentatus, Larosterna inca, Myrmoborus lugubris, Machetornis rixosa, Progne elegans, Conirostrum bicolor) y registros adicionales de Nothoprocta curvirostris y Tyrannus tyrannus. Presentamos el primer registro en Ecuador de tres subespecies (Tolmomyias sulphurescens insignis, Myiarchus swainsoni phaenotus y Oxyura jamaicensis andina, aunque la validez taxonómica de esta última sea debatida). Además, discutimos la identidad subespecífica de Petrochelidon pyrrhonota en el país. Finalmente, invalidamos registros previos de 43 especies del Ecuador continental y 6 especies de Galápagos que aparecen en distintas publicaciones, y rechazamos un registro mediante sensores remotos de Cypseloides niger. CERO revisa y actualiza el listado nacional de aves, que en la actualidad alcanza las 1690 especies (1632 confirmadas y documentadas, 58 no documentadas).

Palabras clave: nuevos registros, extensiones de distribución.

Abstract
We present new distributional records of birds in Ecuador submitted to the Committee for Ecuadorian Records in
Ornithology (CERO) from September 2015 through July 2017. This report includes four species new to Ecuador (Plegadis
ridgwayi, Cathartes burrovianus, Malacoptila mystacalis, Vireo gilvus), two species new to Galapagos (Calidris pugnax,
Larosterna inca), five species with first documented country records (Fregata minor, Syrigma sibilatrix, Calidris pugnax,
Larus belcheri, Sternula antillarum), remarkable range extensions for eight species (Anas bahamensis, Fregata sp., Jabiru
mycteria, Phimosus infuscatus, Caracara cheriway, Larus dominicanus, Chloroceryle aenea, Sturnella militaris), new
records of eight rare species (Anhima cornuta, Mustelirallus albicollis, Larus argentatus, Larosterna inca, Myrmoborus
lugubris, Machetornis rixosa, Progne elegans, Conirostrum bicolor) and new records of Nothoprocta curvirostris and
Tyrannus tyrannus. We present the first Ecuadorian records of three subspecies (Tolmomyias sulphurescens insignis,
Myiarchus swainsoni phaenotus, Oxyura jamaicensis andina, although the taxonomic validity of the latter is debated).
Further we discuss the subspecific identity of Petrochelidon pyrrhonota in Ecuador. Finally, we invalidate previous records

Freile, J. F., Solano-Ugalde, A., Brinkhuizen, D. M., Greenfield, P. J., Lysinger, M., Nilsson, J., Navarrete, L., \& Ridgely, R. S. (2019). Fourth report of the Committee for Ecuadorian Records in Ornithology (CERO) and a revision of undocumented and erroneous records in the literature. Revista Ecuatoriana de Ornitología, 5, 52-79. 
of 43 species for mainland Ecuador and 6 species for Galapagos, as published in different sources, and reject a remotesensing record of Cypseloides niger. CERO revises and updates the country bird list, which currently stands at 1690 species (1632 confirmed and documented; 58 undocumented).

Keywords: new country records, range extensions.

\section{INTRODUCTION}

The growing number of observers publishing field data on the birds of Ecuador and the tremendous amount of information permanently uploaded to online archives (www.macaulay.org, www.xeno-canto.org, www.ebird.org, www.hbw.com) and social media (Davies et al., 2016) are generating an ever-increasing vortex of knowledge about the taxonomy, distribution, ecology, and status of Ecuadorian birds. The Committee for Ecuadorian Records in Ornithology (CERO) was created with the purpose of revising and updating the country's bird list, and to revise novel records. CERO aims to keep the pace with the unending accumulation of field data by revising relevant records uploaded in the aforementioned websites and some social media, or records submitted directly by contributing observers. Furthermore, CERO seeks to contribute to this growing body of information by periodically updating, revising and publishing the 'official checklist of birds of Ecuador' on its webpage: www.ceroecuador.wordpress.com.

Published bird lists for Ecuador and the Galapagos Islands, including the first ever published (Ridgway, 1896; Chapman, 1926), have included species with unconfirmed records in the country. Subsequent monographs, field guides, and checklists (Swarth, 1931; Harris, 1973; Ortiz-Crespo \& Valarezo-Delgado, 1975; Butler, 1979; Ortiz- Crespo et al., 1990; Castro \& Phillips, 1996; Ridgely et al., 1998; Swash \& Still, 2000; Ridgely \& Greenfield, 2001; Wiedenfeld, 2006; McMullan \& Navarrete, 2013; Freile \& Restall, 2018) have incorporated new records, including unproven ones, and have also maintained earlier uncertain records without debate. Recently, Ridgely \& Greenfield (2001) and Wiedenfeld (2006) made a thorough revision of dubious records, providing insightful discussions on the validity of many of them.

With three reports published to date, CERO has updated and revised the national checklist of birds with data reported by several observers from February 1997 through March 2014 (Freile et al., 2013; Nilsson et al., 2014; Freile et al., 2017). To date, CERO has reported 22 new country records (19 species and 3 subspecies), first documented records for 22 species, and significant range extensions for 90 species. Likewise, CERO has removed seven species from the country's bird list due to previous identification or labeling errors (Nilsson et al., 2014; Freile et al., 2017).

This report presents new records received by CERO since its third report, and makes a thorough revision of all checklists published to date, in order to depurate the country list. We also review recent records of species reported for the first time in Ecuador or species with first vouchers. This revision allows us to obtain a validated, official checklist, which currently stands at 1690 species (58 undocumented) (Freile et al., 2018), including the results presented in this fourth report.

\section{METHODS}

CERO receives and reviews records of rare species, new country records, and/or significant range extensions, voluntarily submitted by their authors through CERO's webpage and e-mail address (cero.ecuador@gmail.com). Further, CERO regularly navigates through websites and social media to search for 'rarities,' and requests observers to submit their records or to authorize CERO to evaluate them.

The national country checklist and a list of 'most-wanted' species are published in CERO webpage, allowing observers to consult the status of the birds of Ecuador (https://ceroecuador.wordpress.com). New country records are evaluated and accepted by unanimous vote, while first documentation, undocumented records of previous hypothetical species, and major range extensions are accepted by majority vote.

Most sound-recordings were deposited by observers at xeno-canto online archive (www.xeno-canto.org), for which a XC code and appropriate citation are provided in the species accounts. Photographs are deposited at 
CERO archives, some published online, and the most relevant are published in this report. Locality coordinates and elevation are provided in Table 1 . New country records are marked with an asterisk in the species accounts. Taxonomy and species sequence follow February 2018 version of the South American Classification Committee, SACC (Remsen et al., 2018).

CERO reviewed 36 reports submitted from September 2015 through November 2017, of records obtained by several observers between January 2004 and November 2017, using different survey protocols and documentation techniques. We also made a thorough bibliographic revision of undocumented or likely erroneous records (Tables 2-5).

\section{RESULTS AND DISCUSSION}

\section{Horned Screamer Anhima cornuta}

Los Ríos Province, Puebloviejo, San Juan, ruta San Juan-Vinces, 17 December 2011-12 January 2015, D. Martínez and P. Gastezzi.

Cotopaxi Province, La Libertad near La Maná, October 2014, Xavier Zurita Freire (photo).

Singles, pairs, and small groups were observed at five different sites around Puebloviejo and San Juan towns, and along the road from San Juan to Vinces (Martínez \& Gastezzi, 2014). These authors further observed total of 52-57 individuals at two additional sites near Puebloviejo. The second record, at La Libertad, involves a single bird, recently injured by a shotgun, taken to a local veterinary clinic (Fig. 4a).

These records are the first for the province of Los Ríos (Martínez \& Gastezzi, 2014) and for the lowlands of Cotopaxi (Freile \& Restall, 2018). This recent expansion of the known range of $A$. cornuta is most likely a reflection of incomplete sampling of the avifauna of these little explored regions, not a result of recent range expansion.

\section{White-cheeked Pintail Anas bahamensis}

Carchi Province, laguna El Salado, near San Gabriel, 9 July 2017, W. Arteaga-Chávez and D. Togán (photo).

Three adult birds were observed swimming in open water with a flock of Blue-winged Teal Anas discors (Fig. 3a). Additionally, a solitary individual was recently observed at Yaguarcocha, Imbabura Province, on 22 February 2018 (K. Terán \& P. Imbaquingo, unpubl.). The number of records of this species from the Andes has steadily increased in recent years (Freile et al., 2013; see several recent sightings in https://ebird.org).

\section{Ruddy Duck Oxyura jamaicensis andina}

Imbabura Province, laguna de Yaguarcocha, 4-6 September 2016, W. Arteaga-Chávez, D. Chulde, A. Andi, P. Molina, F. Cifuentes, E. Obando, S. Guerra and L. Calapi (photo).

Three males with white cheeks were observed swimming, resting, and preening in open water (Fig. 5a), not joining groups of the locally common subspecies $O$. jamaicensis ferruginea. Other records include one individual seen by W. Arteaga-Chávez at Lago San Pablo and two at Yaguarcocha, Imbabura Province, on 7 April 2018. Previous records were obtained by J. Nilsson and R. Ahlman at San Pablo in 2016 (Ahlman, 2016b) and further south, at Laguna Micacocha by R. Ahlman in April 2017 (Ahlman, 2017b).

White cheeks, variable individually, make these individuals assignable to the subspecies $O . j$. andina, not previously recorded in Ecuador (Ridgely \& Greenfield, 2001; McMullan \& Navarrete, 2017, Arteaga-Chávez, in press.; but see below). It seems likely that this form is spreading south from central Colombia, but it remains to be determined if a local population is established (or establishing) in northern Ecuador, or if these individuals were only vagrants. The distribution of $O$. jamaicensis andina in Ecuador is currently under revision by $\mathrm{W}$. Arteaga-Chávez (in press.). Co-occurrence of black-headed individuals assignable to $O$. $j$. ferruginea and whitecheeked ones assignable to $O . j$. andina in two localities in northern Ecuador is not novel because similar patterns are regular in the Central and Eastern Andes of Colombia (Fjeldså, 1986; Donegan et al., 2015), but still remarkable given the controversial taxonomic status of both forms (Madge \& Burn, 1988; Livezey, 1995). 
Table 1: Localities of records submitted to the Committee for Ecuadorian Records in Ornithology (CERO) between September 2015 and November 2017. Asterisk indicates additional localities mentioned in the text accounts and tables.

\begin{tabular}{|c|c|c|}
\hline Locality, province & Coordinates & Elevation (m) \\
\hline Ballesteros, Orellana & $-0.9644 /-75.208$ & 190 \\
\hline Bellavista Reserve, Pichincha & $-0.01518 /-78.6889$ & 2250 \\
\hline Borja bypass, Napo* & $0.416 /-77.833$ & c. 1600 \\
\hline Cerro Brujo, Galápagos & $-0.7641 /-89.45841$ & 0 \\
\hline Cerro Oscuro, near Chical, Carchi & $0.94442 /-78.19845$ & $1200-1400$ \\
\hline Charco Vicente, Esmeraldas* & $0.691 /-78.916$ & 150 \\
\hline Chilmá Bajo, Carchi & $0.86667 /-78.075$ & 2070 \\
\hline Daphne Major, Galápagos & $-0.4248 /-90.3671$ & 0 \\
\hline Ecuasal Mar Bravo, Santa Elena & $-2.2167 /-80.967$ & 0 \\
\hline El Carmen de Putumayo, Sucumbíos & $0.118 /-75.856$ & 220 \\
\hline Derna, Orellana* & $-0.4432 /-76.6713$ & 230 \\
\hline Gardner Bay, Galápagos & $-1.34406 /-89.6494$ & 0 \\
\hline Guacamayu River, Orellana* & $-0.4613 /-76.8558$ & 240 \\
\hline Gualaquiza, Morona Santiago* & $-3.38972 /-78.5719$ & c. 900 \\
\hline Guango Lodge, Napo & $-0.37097 /-78.0816$ & 2000 \\
\hline Jardín Botánico de Quito, Pichincha & $-0.183 /-78.483$ & 2800 \\
\hline Laguna El Salado, Carchi & $0.5827 /-77.7886$ & 2780 \\
\hline Laguna Yaguarcocha, Imbabura & $0.3666 /-78.0833$ & 2200 \\
\hline La Bonita, below, Sucumbíos* & $0.46102 /-77.5654$ & 1800 \\
\hline La Libertad, near La Maná, Cotopaxi & $-0.9408 /-79.2236$ & c. 220 \\
\hline La Selva, Sucumbíos & $-0.416 /-76.133$ & 250 \\
\hline Las Peñas, $10 \mathrm{~km} \mathrm{~N}$, Esmeraldas & $1.0996 /-79.15205$ & 0 \\
\hline Limpiopungo, Pichincha & $-0.6428 /-78.4848$ & 3890 \\
\hline Manta, Manabí, 3-5 km W, Manabí & $-1.1012 /-81.0205$ & 0 \\
\hline Miazi, Zamora Chinchipe* & $-4.2874 /-78.6350$ & 900 \\
\hline Micacocha, Napo* & $-0.5455 /-78.2118$ & 3900 \\
\hline Mindo, Pichincha* & $-0.054 /-78.7786$ & 1250 \\
\hline Nuevo Rocafuerte (river islands), Orellana & $-0.92105 /-75.3866$ & 190 \\
\hline Pedernales-San Vicente road, Manabí & $0.0288 /-80.0922$ & 4 \\
\hline Playa de Oro, Esmeraldas* & $0.84847 /-78.7822$ & c. 150 \\
\hline Puebloviejo, Los Ríos & $-1.5854 /-79.5822$ & 20 \\
\hline Puerto Baquerizo Moreno, Galápagos & $-0.93805 /-89.6104$ & 0 \\
\hline Punta Cormorant, Galápagos & $-1.22744 /-90.4257$ & 0 \\
\hline Punta Moreno, Galápagos & $-0.6718 /-91.2191$ & 0 \\
\hline Punta Pitt, Galápagos & $-0.6954 /-89.26737$ & 0 \\
\hline Punta Suárez, Galápagos* & $-1.3699 /-89.7340$ & 0 \\
\hline Río Napo, island near Añangu, Orellana & $-0.51863 /-76.3785$ & 220 \\
\hline Río Topo, Tungurahua* & $-1.4 /-78.2$ & c. 1600 \\
\hline Roca Montañita, Santa Elena* & $-1.81926 /-80.7615$ & 0 \\
\hline Ruta San Juan-Vinces, Los Ríos & $-1.66705 /-79.6049$ & 20 \\
\hline Sacha Lodge, Sucumbíos & $-0.47506 /-76.459$ & 230 \\
\hline Same, Esmeraldas* & $0.8491 /-79.9269$ & 0 \\
\hline San Juan, Los Ríos & $-1.6333 /-79.5603$ & 10 \\
\hline San Lorenzo, Esmeraldas* & $1.3026 /-78.8548$ & 0 \\
\hline San Vicente on Río Napo, Orellana & $-0.6946 /-75.587$ & 200 \\
\hline Sani Isla, Orellana* & $-0.47708 /-76.2943$ & 200 \\
\hline Santa Rosa, Santa Elena & $-2.211 /-80.948$ & 0 \\
\hline Tababela Airport, Pichincha & $-0.1 /-78.35$ & 2350 \\
\hline Teleférico de Quito, Pichincha & $-0.18661 /-78.5371$ & 4050 \\
\hline Tinalandia, Santo Domingo de los Tsáchilas* & $-0.2975 /-79.0517$ & 650 \\
\hline Tiputini, Orellana & $-0.8078 /-75.523$ & 200 \\
\hline Tipischa (1.3 km N), Sucumbíos & $0.283 /-76.167$ & 230 \\
\hline Tufiño, Carchi & $0.8003 /-77.8553$ & 2954 \\
\hline Valladolid, Zamora Chinchipe* & $-4.53972 /-79.1327$ & c. 1600 \\
\hline Vinillos, Napo & $-0.605 /-77.8416$ & 2100 \\
\hline Wildsumaco, Napo* & $-0.676 /-77.601$ & 1600 \\
\hline Zamora, Zamora Chinchipe* & $-4.06208 /-78.9486$ & c. 900 \\
\hline
\end{tabular}


Variation in cheek pattern is considerable throughout the range of $O . j$. andina (del Hoyo et al., 2018), suggesting that this region is an old, wide hybrid zone (a hybrid swarm; Fjeldså, 1986; Livezey, 1995). Consequently, the validity of subspecies $O . j$. andina has been questioned. Some authors consider it a valid subspecies of $O$. jamaicensis (Clements et al., 2017), while others regard it as a hybrid that justifies lumping $O$. jamaicensis and $O$. ferruginea as a single species, because andina acts as an intergraded form between whitecheeked jamaicensis and black-headed ferruginea (Fjeldså, 1986; McCracken \& Sorenson, 2005; MuñozFuentes et al., 2013; Donegan et al., 2015). Conversely, other authors suggest separating $O$. jamaicensis and $O$. ferruginea, but invalidate the subspecies andina due to its putative hybrid origin (Livezey, 1995; del Hoyo et al., 2018). The taxonomy of these taxa needs further clarification.

\section{Frigatebird Fregata sp.}

Orellana Province, close to San Vicente on Río Napo, 5 September 2016, J. Nilsson (photo).

One adult male was observed soaring 50-500 $\mathrm{m}$ above ground, c. 1 hour by motorized canoe west of Tiputini (Fig. 3b). Identification to species was not possible due to light conditions and distance to the bird. This represents the first documented record of a frigatebird from the Ecuadorian Amazon, but there is an additional sight record of another unidentified frigatebird from 2010 by José Illanes (pers. comm.), upriver from Sani Isla.

\section{Great Frigatebird Fregata minor}

Manabí Province, 3-5 km offshore Manta, 22 March 2016, S. Howell, C. Parliament, D. Parliament, J. Gaetzi, P. Vranicar, F. Schmitt (photo).

One immature (third year) bird was observed flying low overhead (Fig. 2a). One observer (S. Howell) has extensive experience with frigatebird identification, and photographs allowed a careful study of key characters (Howell, 1994).

This represents the first documented record in continental Ecuador, with a previous sighting (31 May 1987) from Roca Montañita, Santa Elena Province (Haase, 2011). It remains plausible that the species has been overlooked in continental Ecuador given the identification difficulties (Howell, 1994). Individuals with reddish legs have been observed in the mangroves of the San Lorenzo area, Esmeraldas province (J. Freile, A. SolanoUgalde, F. Prieto \& P. Moscoso, unpubl.). Leg colour has been considered a field mark (Howell, 1994), but some individuals observed at San Lorenzo were actually reddish-legged female Magnificent Frigatebirds Fregata magnificens. Further study of field characters in these two species is still needed.

\section{Jabiru Jabiru mycteria}

Esmeraldas Province, 10 km N of Las Peñas, 21 December 2016, C. Vogt (photo).

A single bird was observed in a freshwater grassy marsh with large fern clumps (Fig. 3c). It remained standing on the ground with little movement but was flushed easily, moving large distances. After first sighting, it flew off and was seen again $2.5 \mathrm{~km}$ south and flushed easily once again. Seen and photographed the next day by R. Ahlman. This represents the first confirmed record from western Ecuador; there is one undocumented sighting from Manglares-Churute, Guayas Province (Freile \& Restall, 2018).

\section{Whistling Heron Syrigma sibilatrix}

Sucumbíos Province, El Carmen de Putumayo, 18 January 2017, D. Jumbo, R. Ahlman (photo).

One adult bird observed and photographed (Fig. 2b) in open habitat; record first uploaded to eBird (Ahlman, 2017a), and later submitted to CERO by J. Freile. This represents the first documented record in Ecuador, where it was previously known from one unvouchered observation from El Puma, E of Coca, Orellana Province, along the Napo River (Mena \& Jahn, 2003). There are a few more recent records, to be submitted to CERO, from the Amazon lowlands and northern Andes.

\section{*Puna Ibis Plegadis ridgwayi}

Pichincha Province, laguna de Limpiopungo, 3 January 2015, Y. Potaufeu (photo). 
One adult bird was seen wading in shallow water for 2 min, making its way to a small vegetation island (Fig. 1a). It was later relocated by R. Ahlman and R. Gelis on 13 January and observed by D. Brinkhuizen, C. Vogt and other observers until 15 January 2015. This represents the first record for Ecuador, $500 \mathrm{~km}$ north of the northernmost records in Peru (Schulenberg et al., 2007; Jiménez-Gonzales, 2018).

a

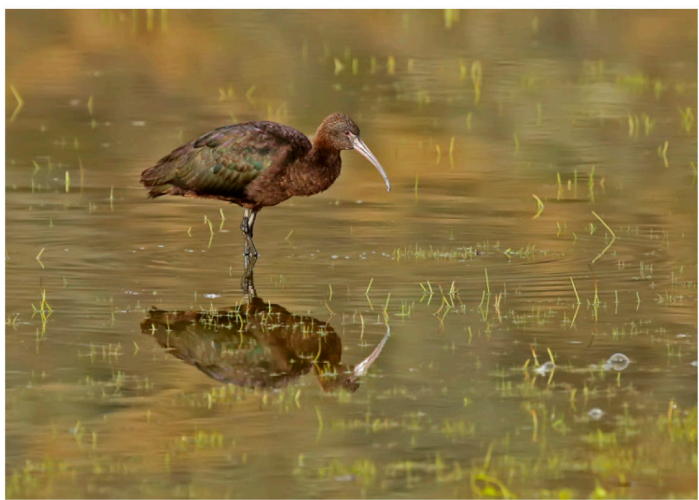

b

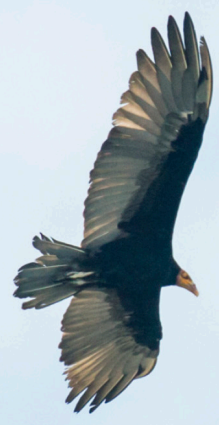

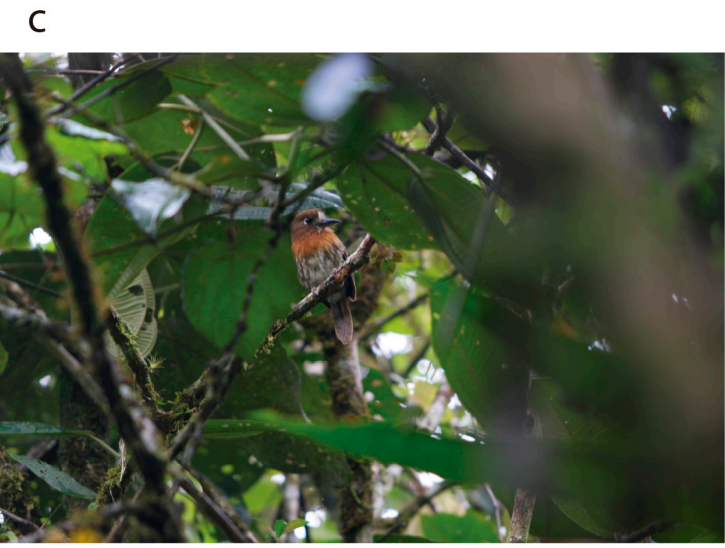

d
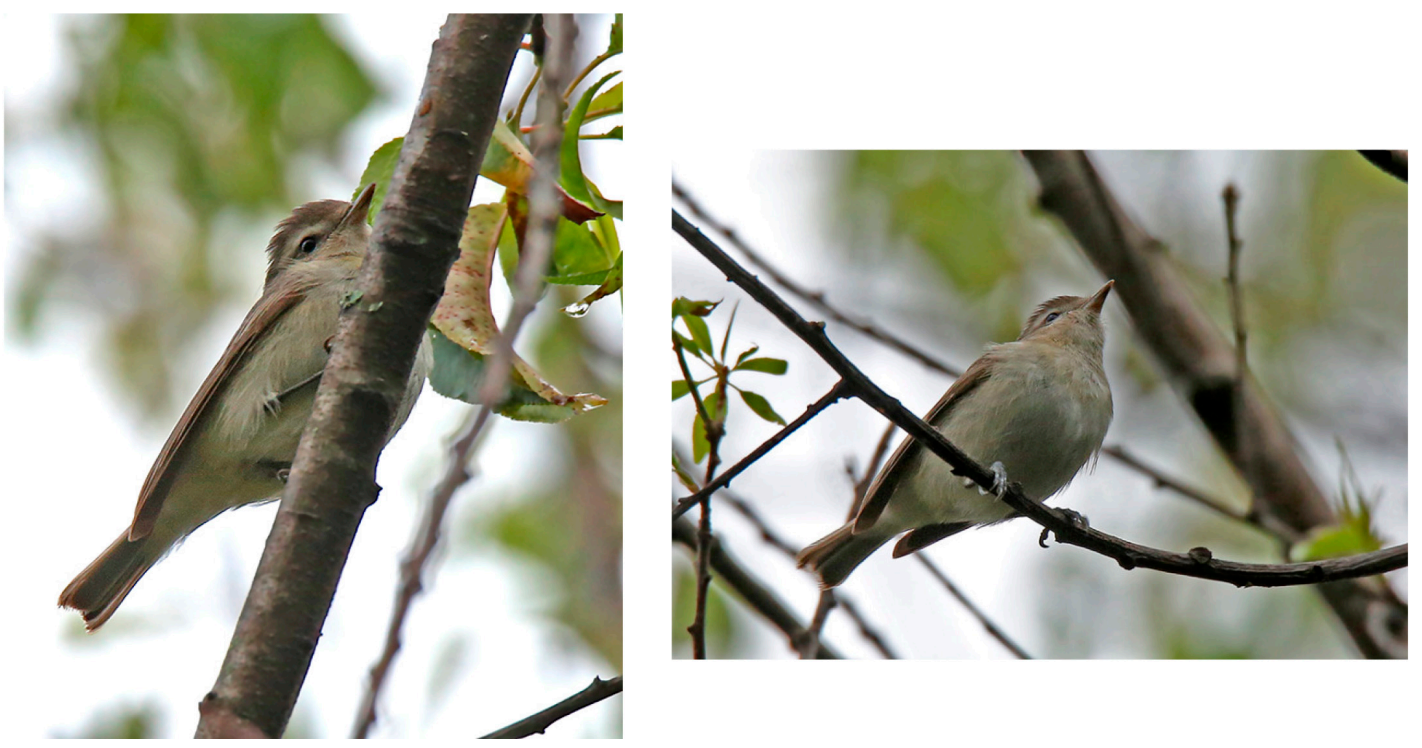

Figure 1: New country records for Ecuador. a) Plegadis ridgwayi, Limpiopungo, Cotopaxi Province (R. Ahlman); b) Cathartes burrovianus, Río Napo, Orellana Province (N. Athanas); c) Malacoptila mystacalis, Chical, Carchi Province (A. Boas); d) Vireo gilvus, Quito, Pichincha Province (R. Ahlman). 


\section{Bare-faced Ibis Phimosus infuscatus}

Carchi Province, Chilmá Bajo, 10 March 2016, H. A. Pozo Ruano and J. M. Loaiza (photo).

A single bird was observed feeding at muddy pastureland from 10 March 2016 through 3 December 2016, often associated with Southern Lapwing Vanellus chilensis and Spotted Sandpiper Actitis macularius (Fig. 3d). This is the first record west of the Andes in Ecuador, after an increasing number of records in the northeast lowlands (Freile et al., 2013; Freile \& Restall, 2018). The species occurs along the Cauca valley of central Colombia (McMullan \& Donegan, 2014), but likely spread to northwest Carchi across the Andes in the Carchi-Nariño region. An observation of five individuals below La Bonita, Sucumbíos Province (J.M. Loaiza, J.F. Freile \& P. Molina, unpubl.), on 1 February 2016, partially supports our suggestion of trans-Andean spreading.

\section{*Lesser Yellow-headed Vulture Cathartes burrovianus}

Orellana Province, Ballesteros, 30 August-4 September 2016, J. Nilsson (photo).

Orellana Province, river island near Añangu, 14 December 2016, N. Athanas (photo).

The first of these records involved at least four individuals (one adult, one juvenile, and two immatures) observed on a small river island in front of the military post at Ballesteros, in front of Nuevo Rocafuerte, and at the old airstrip east of Nuevo Rocafuerte. The second record involved one individual observed circling above a young river island near Añangu (Fig. 1b). The habitats involved in these records included the edge of mature Cecropia woodland, sparsely vegetated river islands, and open grassy fields bordered by secondary forest. Subsequent sightings have further documented the presence of this species in Ecuador, including two near the mouth of Guacamayu River by L. Navarrete et al. (Frost, 2017); and one in Derna area, 10 min down river from Coca and another individual near Añangu (Ahlman, 2017d).

Even though Tallman \& Tallman (1977) reported one sighting from Limoncocha, there have been no additional observations from the Napo River area since then. Ridgely \& Greenfield (2001) regarded this early observation as dubious, but habitat changes might have facilitated the species recent colonisation from neighbouring Peru along the Napo River.

\section{Crested Caracara Caracara cheriway}

Carchi Province, Tufiño, 16 June 2017, G. Herrera-Villareal and W. Arteaga-Chávez (photo).

Two individuals were observed for several weeks in the Ecoparque de Tufiño (Fig. 3e). The species is locally and sporadically found in the Andean valleys of northern Ecuador (Ridgely \& Greenfield, 2001; Freile \& Restall, 2018), but it remains to be determined if it was formerly a resident breeder that has drastically declined or if it only wanders into the northern Andean valleys (Ridgely \& Greenfield, 2001). This record is also among the highest in elevation, but there are additional recent records from the northern Andes (Tellkamp, 2016, 2017; Ahlman, 2018b).

\section{Ash-throated Crake Mustelirallus albicollis}

Sucumbíos Province, 1.3 km N Tipishca, 10-11 December 2014, R. Ahlman and D. Brinkhuizen (audio recording).

Two birds were heard and audio-recorded in a marshy area with low grass vegetation, some open water, sparse bushes and small trees (Brinkhuizen, 2014; XC 206291). They responded to playback only at this site; trials at other sites with taller grass were unsuccessful. This is the second known locality for this species in Ecuador, where it was previously known only from Sacha Lodge, Orellana Province (Nilsson et al., 2014). One additional, more recent record, was obtained by R. Ahlman (in litt., September 2019) at El Carmen de Putumayo, province of Sucumbíos, where first recorded in May 2016. At this locality, at least two or three pairs are regularly heard within earshot.

\section{Ruff Calidris pugnax}

Galápagos Province, playa Cerro Brujo, San Cristóbal Island, 2 August 2016, O. Campbell (photo). 
A single adult male in non-breeding plumage was observed in a saline pool with dried mud, right behind the beach, feeding alone or in loose association with Black-necked Stilt Himantopus mexicanus (Fig. 2c). Distance to the photographed bird was $50-75 \mathrm{~m}$.

This represents the first documented record of C. pugnax from Galapagos and Ecuador, which was only recently published (Campbell, 2018). The only previous country record is an uncorroborated sighting in inner Guayas Province (R. Ahlman; see Freile \& Restall, 2018).

a
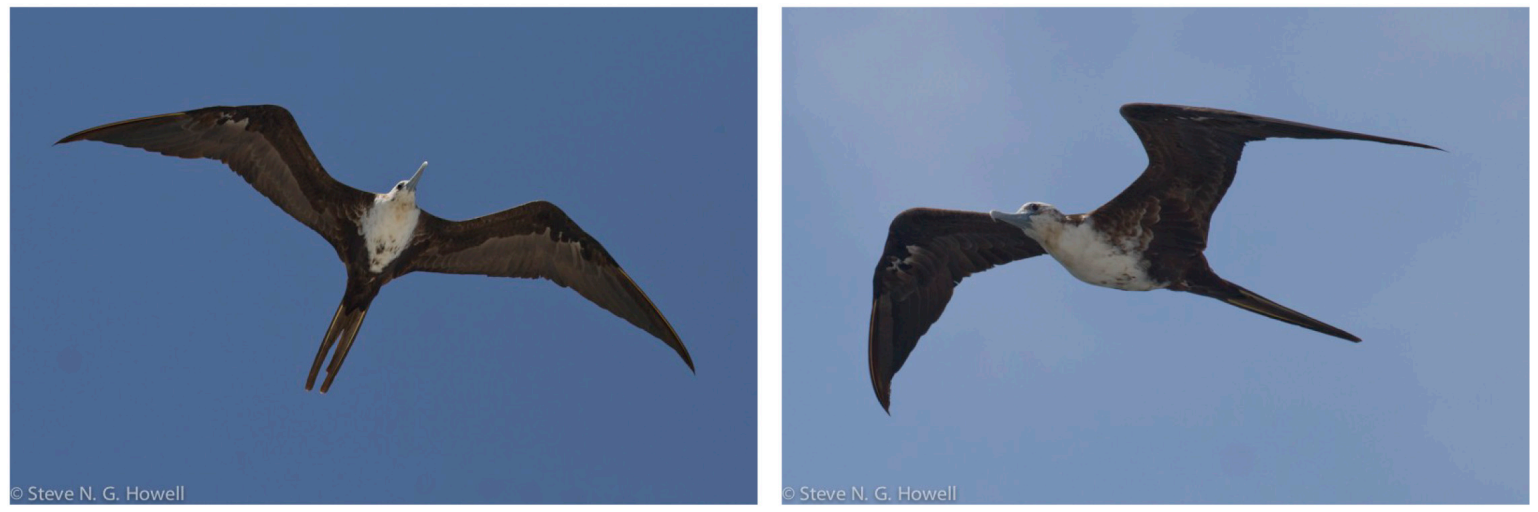

b

C
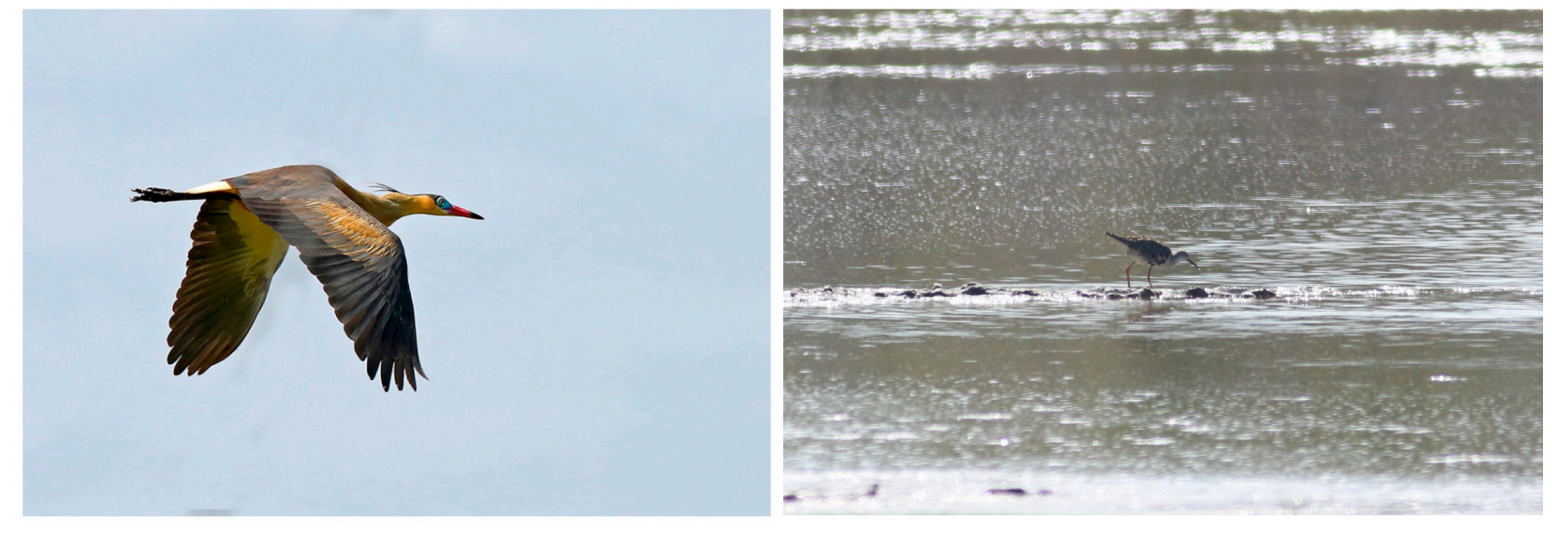

d

e
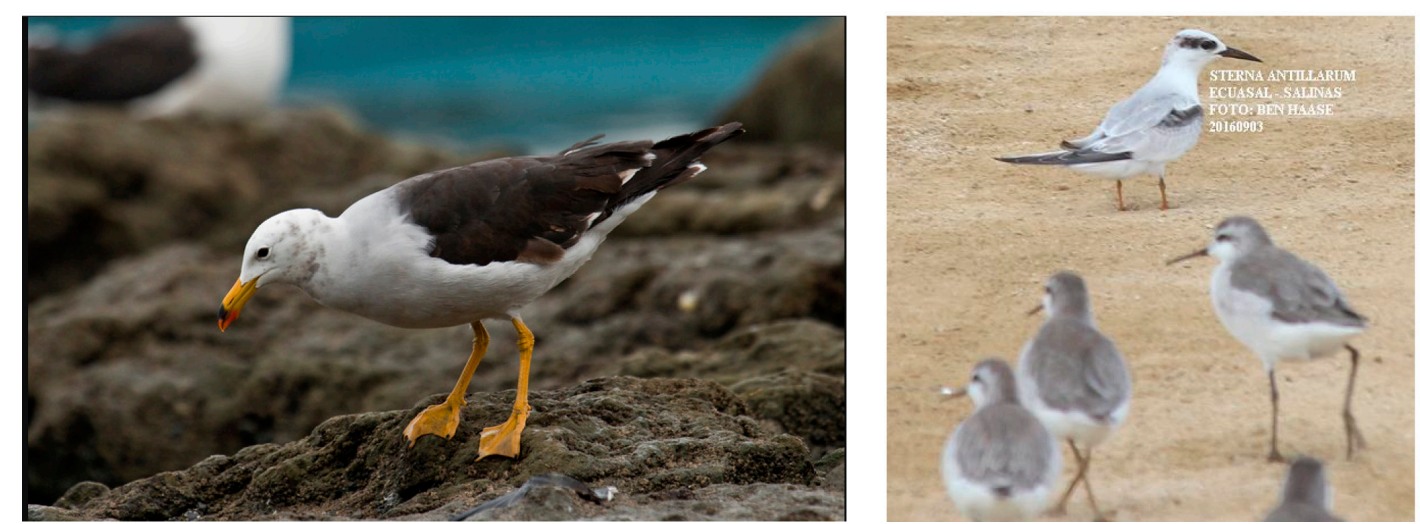

Figure 2: First documented records of species previously considered as hypothetical in Ecuador. a) Fregata minor, Manta, Manabí Province (S. Howell); b) Syrigma sibilatrix, El Carmen de Putumayo, Sucumbíos Province (R. Ahlman); c) Calidris pugnax, San Cristóbal, Galápagos Province (O. Campbell); d) Larus belcheri, Santa Rosa, Santa Elena Province (D. M. Brinkhuizen); e) Sternula antillarum, Mar Bravo, Santa Elena Province (B. Haase). 


\section{Belcher's Gull Larus belcheri}

Santa Elena Province, Santa Rosa, peninsula de Santa Elena, 25 September 2015, D. M. Brinkhuizen (photo).

One bird seen foraging on a rocky shore (Fig. 2d), loosely associated with other gulls, including Kelp Gull Larus dominicanus. Previously published records all pertain to undocumented observations (Ridgely \& Greenfield, 2001; Haase, 2011), making the Santa Rosa photographs the first vouchered record in Ecuador. There are additional, more recent, records that will be revised by CERO in due course.

\section{Kelp Gull Larus dominicanus}

Pichincha Province, Tababela (Quito) Airport pond, 13-22 January 2017, J. Nilsson (photo).

One adult was observed in an artificial pond (Fig. 3f), representing the first record in the Andes of Ecuador and the highest record throughout its range (Howell \& Dunn, 2007).

\section{Herring Gull Larus argentatus}

Manabí Province, Pedernales-San Vicente road, 13 February 2017, M. Sánchez, T. Santander, E. Guevara and M. Ellis (photo).

One immature (second year) individual was observed in a shrimp pond near Pedernales (Fig. 4b). This is the third record in Ecuador and the first coastal record (Freile \& Restall, 2018) of the L. argentatus smithsonianus subspecies, which is often regarded as a separate species (Crochet et al., 2002).

\section{Inca Tern Larosterna inca}

Galápagos Province, Daphne Major, J. C. Manosalvas and G. Jiménez-Uzcátegui; Punta Cormorant (Floreana) and Punta Moreno (Isabela), C. Carrión; Puerto Baquerizo Moreno (San Cristóbal), A. Villa; Gardner Bay (Española) and Punta Pitt (San Cristóbal), L. D. Dejean, E. Stucki, C. Larrea, D. Degel, G. Loza, C. King and S. Estupiñan (photos).

The first of these records in Galápagos involves a solitary adult seen and photographed on the rocky shores of Daphne Major in 14 August 2008, where it was seen again 3 days later (Fig. 6a). This record was published, albeit without voucher photos (Jiménez-Uzcátegui \& Manosalvas, 2010). Two subsequent records were obtained by naturalist guides, first involving possibly the same bird first seen in Punta Cormorant (Floreana) and later in Punta Moreno (Isabela) on an unspecified date in 2011 by C. Carrión; and another individual seen at Puerto Baquerizo Moreno (San Cristóbal) on an unspecified date in 2015 by A. Villa (both pers. comm. to G. Jiménez-Uzcátegui).

More recently, a single bird in adult plumage was first located by L. D. Dejean when it landed on a boat's deck near Gardner Bay, Española, on 2 April 2017 (Fig. 6b). The bird remained the whole day and was later seen at other locations throughout the central and southwest islands (Punta Pitt and Puerto Baquerizo Moreno, San Cristóbal; Punta Suárez, Española; Puerto Ayora, Santa Cruz) until late April 2017. These records are the first documented for the Galápagos Archipelago, but one earlier record, supported with a photograph, is available in eBird (Megyesi, 2015). Another record, though unvouchered, is also available (Jaramillo, 2008).

\section{Least Tern Sternula antillarum}

Santa Elena Province, Ecuasal Mar Bravo, 3 September 2016, B. Haase (photo).

One immature was photographed (Fig. 2e) perched on a sandy ditch amongst a flock of waders. There are a few unvouchered records in coastal Ecuador between August and November (Ridgely \& Greenfield, 2001; Haase, 2011). The first published photograph taken in Ecuador (B. Haase, pers. comm., 2018) appeared in Haase (2011), but it was not labeled as taken in Ecuador. The 2016 record was submitted to CERO without a supporting form, and will also be published in due course along with five additional records, three supported with photos (B. Haase, pers. comm., 2018). 
a

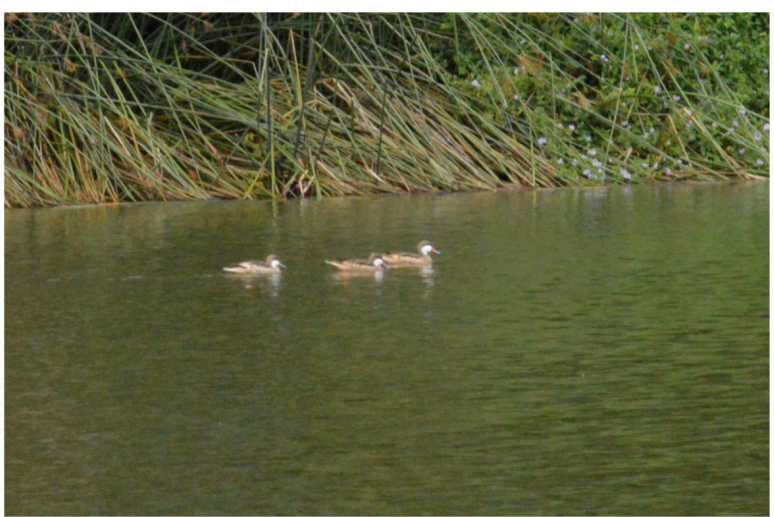

b

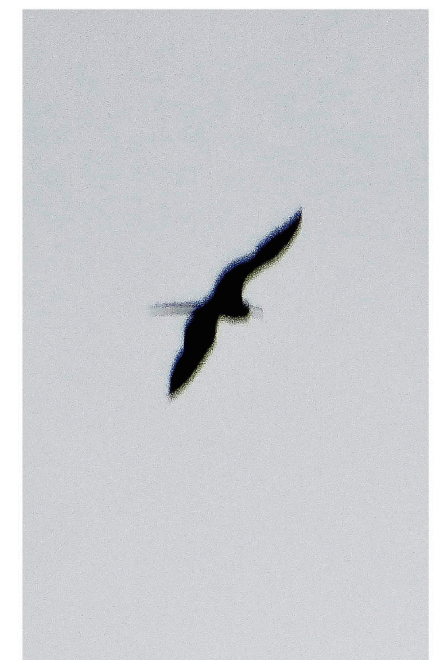

C
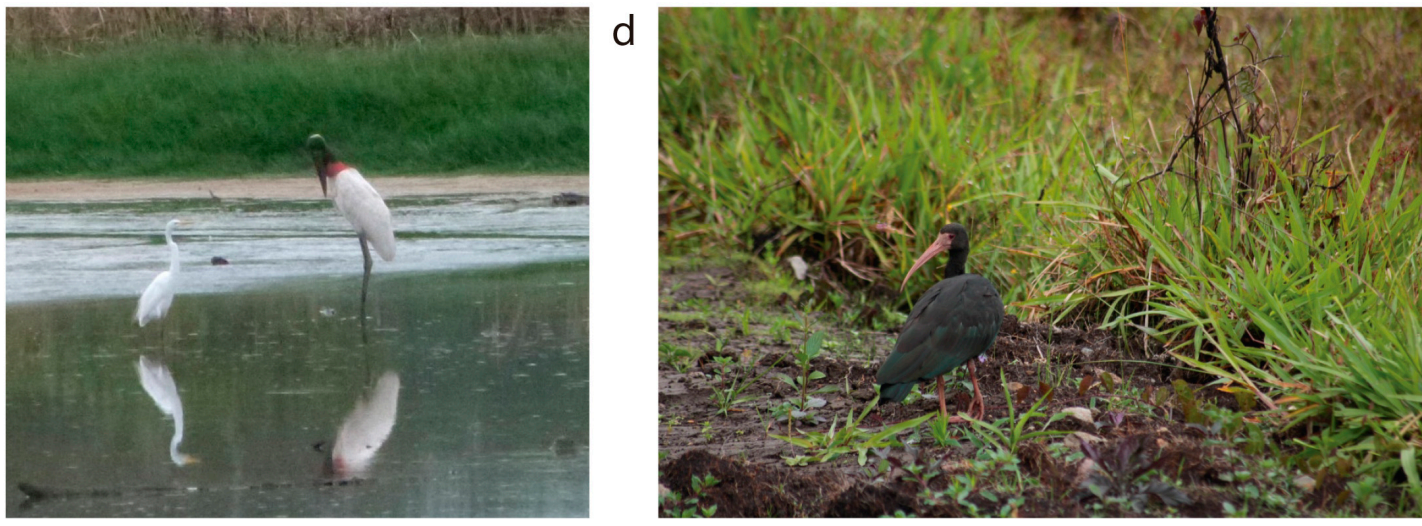

e

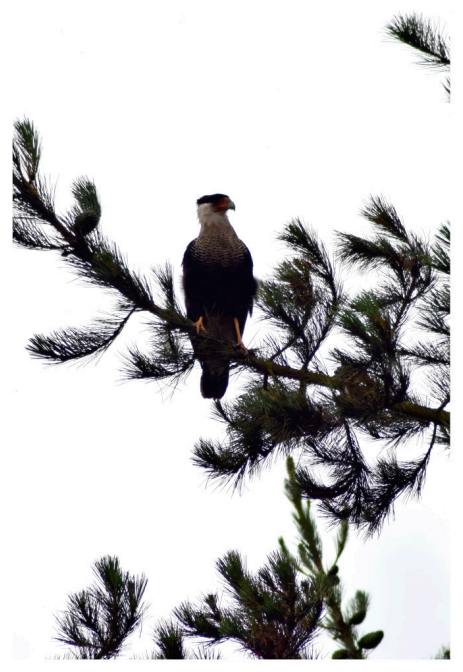

$f$

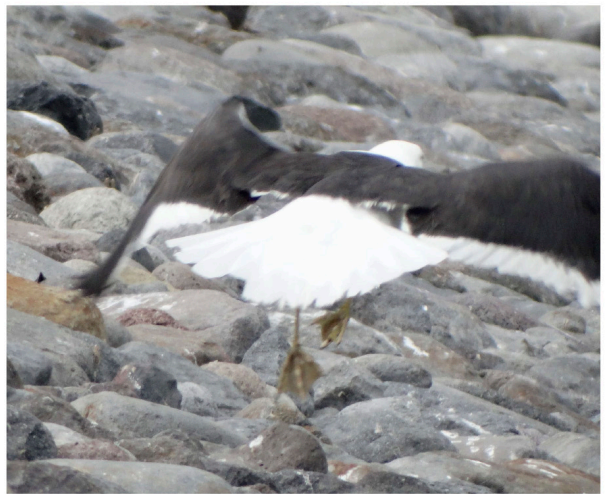

g

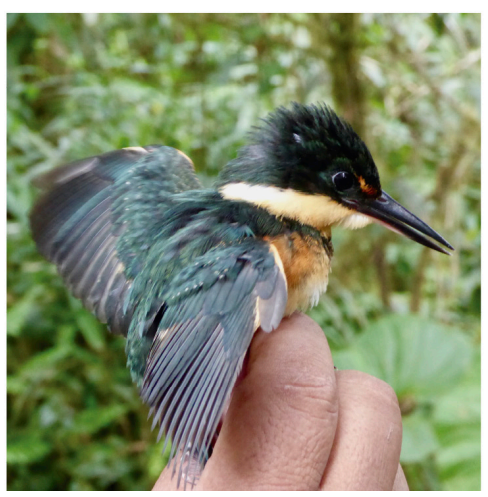

Figure 3: Major range extensions and extralimital records of birds in Ecuador. a) Anas bahamensis, El Salado, Carchi Province (W. Arteaga-Chávez); b) Fregata sp., San Vicente, Orellana Province (J. Nilsson); c) Jabiru mycteria, Las Peñas, Esmeraldas Province (C. Vogt); d) Phimosus infuscatus, Chilmá Bajo, Carchi Province (J. M. Loaiza); e) Caracara cheriway, Tufiño, Carchi Province (G. Herrera-Villareal); f) Larus dominicanus, Tababela, Pichincha Province (J. Nilsson); g) Chloroceryle aenea, Bellavista, Pichincha Province (C. D. Becker). 


\section{American Pygmy Kingfisher Chloroceryle aenea}

Pichincha Province, Bellavista Reserve, 26 July 2017, D. Becker, K. Shaw (photo).

One adult female was mist-netted, measured, and photographed (Fig. 3g) inside mature forest, not in close proximity to any body of water. The species has been recorded mainly below $400 \mathrm{~m}$ elevation in the Pacific lowlands (Freile \& Restall, 2018), with a few records from the foothills and lower slopes (i.e., Tinalandia, Mindo valley; Ridgely \& Greenfield, 2001) and an exceptional record in Quito (Nilsson et al., 2014).

\section{* Moustached Puffbird Malacoptila mystacalis}

Carchi Province, Cerro Oscuro, Dracula Reserva near Chical, 11 August 2017, J. M. Loaiza, J. C. Crespo and A. Boas (photo, audio-recording, video).

Up to four birds (two pairs) were heard and observed at two sites, the first pair in a riparian secondary forest with fairly open understorey, at 1,200 $\mathrm{m}$ a.s.l., and the second in a mature forest ridge with dense understorey, at 1,400 $\mathrm{m}$ (Loaiza et al., 2019). These records are supported by photographs, audio-recordings and video (Fig. 1c), and represent the first records of the species in Ecuador, but Chical is less than $40 \mathrm{~km}$ south of the nearest locality in Colombia (Reserva La Planada, Nariño department; Loaiza et al., 2019). This discovery is not entirely unexpected (Ridgely \& Greenfield, 2001).

\section{a}

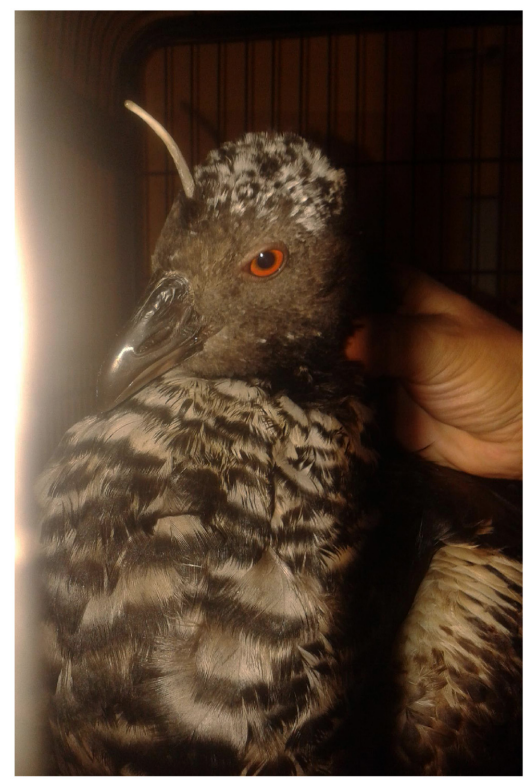

c

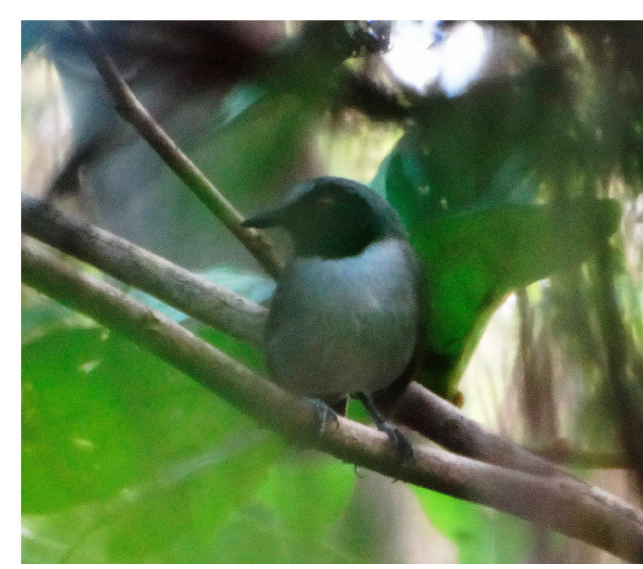

b

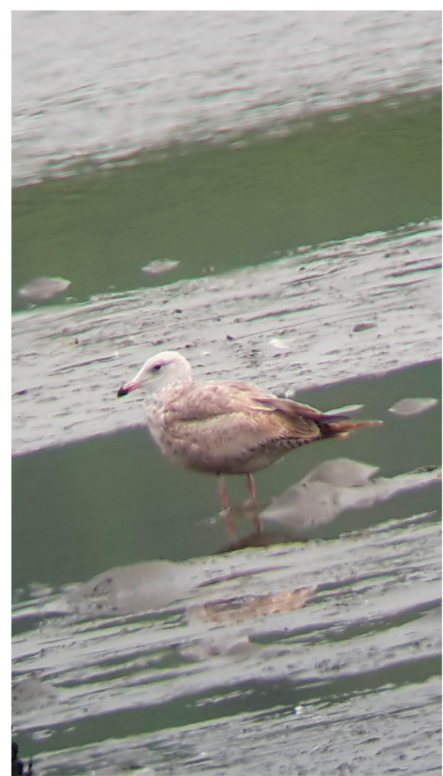

d

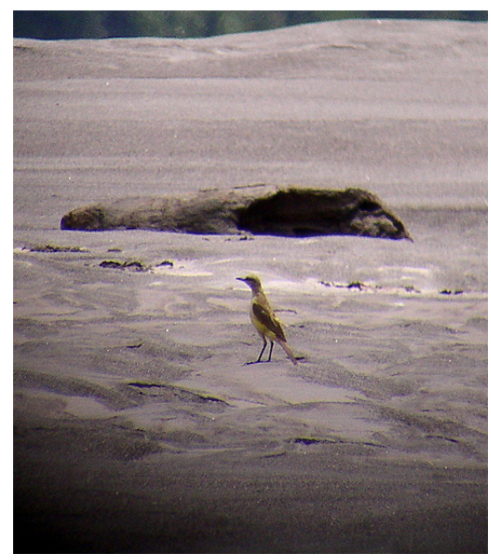

Figure 4: Rare birds recorded in Ecuador. a) Anhima cornuta, La Maná, Cotopaxi Province (X. Zurita); b) Larus argentatus, Pedernales, Manabí Province (M. Sánchez-Nivicela); c) Myrmoborus lugubris, Nuevo Rocafuerte, Orellana Province (J. Nilsson); d) Machetornis rixosa, Río Napo, Sucumbíos Province (G. Rosenberg). 


\section{Ash-breasted Antbird Myrmoborus lugubris}

Orellana Province, river islands near Nuevo Rocafuerte, 30 August-4 September 2016, J. Nilsson (photo).

Found as a relatively common species on four different river islands with mature forest between Nuevo Rocafuerte and the border with Peru, in fairly dense to somewhat more open undergrowth (Fig. 4c). It was previously known from a single island near the mouth of the Río Aguarico on the Río Napo (Ridgely \& Greenfield, 2001).

\section{Yellow-olive Flycatcher Tolmomyias sulphurescens}

Sucumbíos Province, Sacha Lodge, 20 February 2015, D. Lane (photo, audio-recording).

At least four individuals were heard and seen in river edge forest of medium height (Fig. 5b, Lane, 2015a; XC $214585,214587)$. They generally perched at mid-levels and in understory, as well as around openings at the lodge's river-edge landing area. First noticed when four birds were interacting, either two territorial pairs or family members. They responded territorially to playback of their own vocalizations. The next day, a pair was encountered in understory, but after playback, the presumed male sang from the upper mid-story. Photos are uploaded at the observer's personal online archive https://www.flickr.com/photos/ 8013969@N03/16417378107/in/photostream/.

This represents the first record of $T$. sulphurescens in the Amazonian lowlands of Ecuador, since the species has previously been reported in the east Andean foothills to subtropics (subspecies T. s. confusus and T. s. peruvianus) and western lowlands to subtropics (subspecies T. s. aequatorialis; Freile \& Restall, 2018). Plumage and vocal characters of birds in the Amazon lowlands correspond to subspecies T. sulphurescens insignis, previously known from riparian habitats in Loreto Department, northeast Peru, and adjacent western Brazil (Clements et al., 2017). Contra Schulenberg \& Parker (1997), T. sulphurescens insignis concurs with Orange-eyed Flycatcher T. traylori in the Napo region, including records in Sacha Lodge and possibly other localities along the Río Napo. It seems plausible that these two taxa segregate by habitat when syntopic. A thorough assessment of geographic variation in $T$. sulphurescens might reveal that several subspecies, including T. s. insignis, deserve species status (Ridgely \& Greenfield, 2001; Fitzpatrick et al., 2004).

\section{Cattle Tyrant Machetornis rixosa}

Sucumbíos Province, Río Napo in front of La Selva Lodge, 13 January 2004, D. Lane, G. Rosenberg (photo).

One adult was observed on a sandbar in the Río Napo (Fig. 4d). Although the species is now well-established and likely spreading following deforestation, first records date back to the early 2000 s (Ridgely \& Greenfield, 2006). This early record from a sandbar along the Napo might suggest that the species is expanding its range along the Napo from northern Peru. However, there are no records along this river in northern Peru, but an increasing influx of records in the southern Colombian Amazon (eBird, 2018), which suggests it as the actual immigration pathway. Furthermore, one bird was seen perching temporarily at the canopy walkway of Sacha Lodge (Lilley, 2019), suggesting that M. rixosa is able to disperse over vast tracts of forest.

\section{Swainson's Flycatcher Myiarchus swainsoni}

Sucumbíos Province, Sacha Lodge, 22 January 2010, D. Lane (photo, audio-recording).

Several birds were seen and heard along open lake edges with stands of arum and palms (Fig. 5c, Lane, 2010; XC 257112, 257113). The species is a year-round breeding resident in Sacha Lodge, as indicated by calls of recently fledged juveniles available in Moore et al. (2013) and regular territorial singing. However, no nests have yet been found. Additional recordings from the same locality are available in Xeno-Canto (Lysinger, 1995; XC 260956, 260957; Lane, 2015b; XC 214547), as well as from nearby Añangu (Moore, 2005; XC 258958). Photos have been uploaded at the observer's personal online archive (https://www.flickr.com /photos/8013969@N03/16598858736/in/photostream/).

The species was previously known as an austral migrant to Amazonian Ecuador, found from April through September, with two subspecies recorded (M. s. ferocior and M. s. swainsoni) (Ridgely \& Greenfield, 2001; Freile \& Restall, 2018). These two subspecies have largely pale mandibles, and $M$. s. ferocior has a distinctly masked appearance (Freile \& Restall, 2018). Slight plumage and soft part color differences suggest that $M . s$. 
phaeonotus is the subspecies breeding in Ecuador. This subspecies ranges mainly in southeast Venezuela, western Guyana, and northern Brazil (Fitzpatrick et al., 2004), with the closest records in Amazonas State, Brazil (B. M. Whitney, unpubl.) and Mitu Department, Colombia (Spencer, 2011). It remains to be determined if breeding birds in Amazonian Ecuador (and likely Colombia and northern Peru) are actually M. s. phaeonotus or an undescribed cryptic taxon. Until its status is further investigated, we accept this record as M. s. phaeonotus.

a
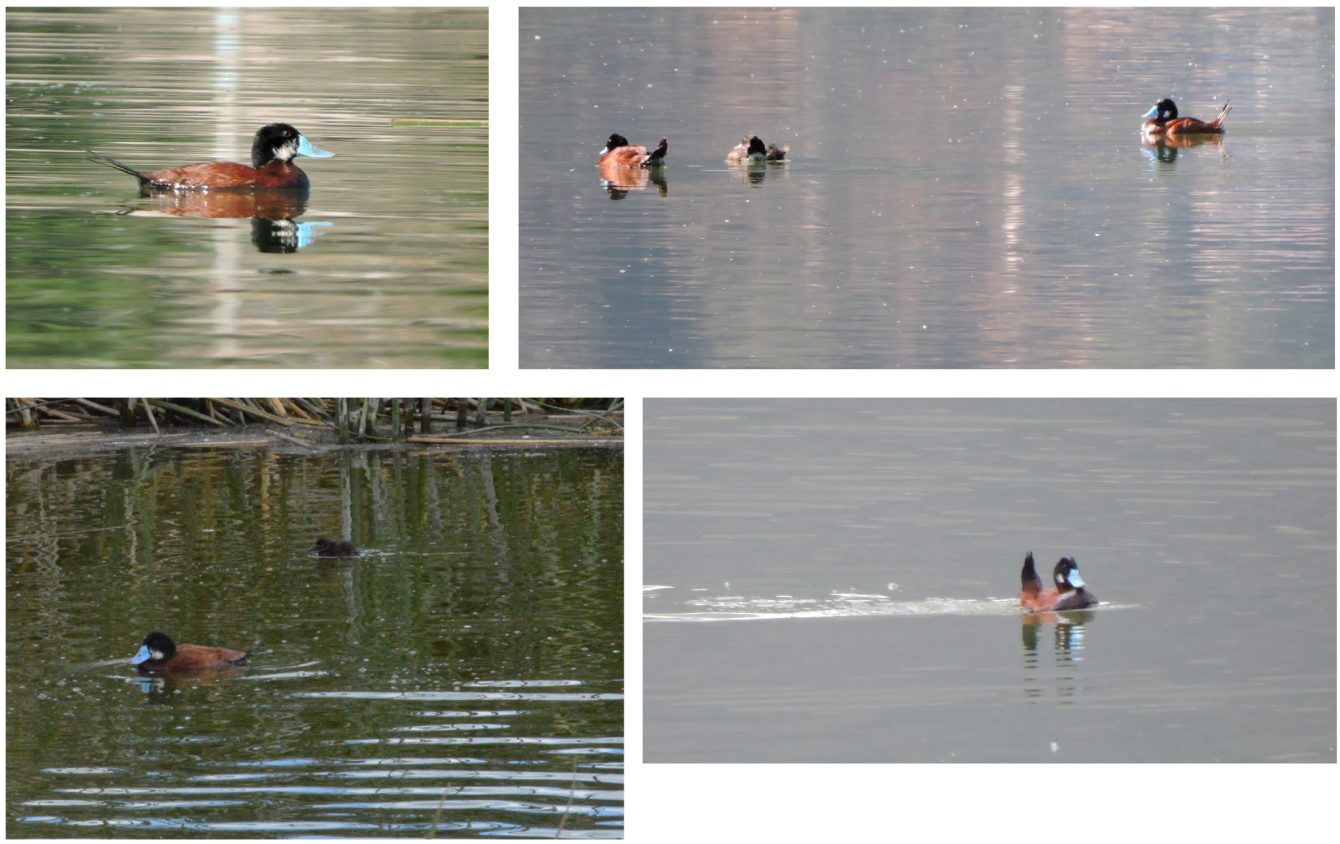

b
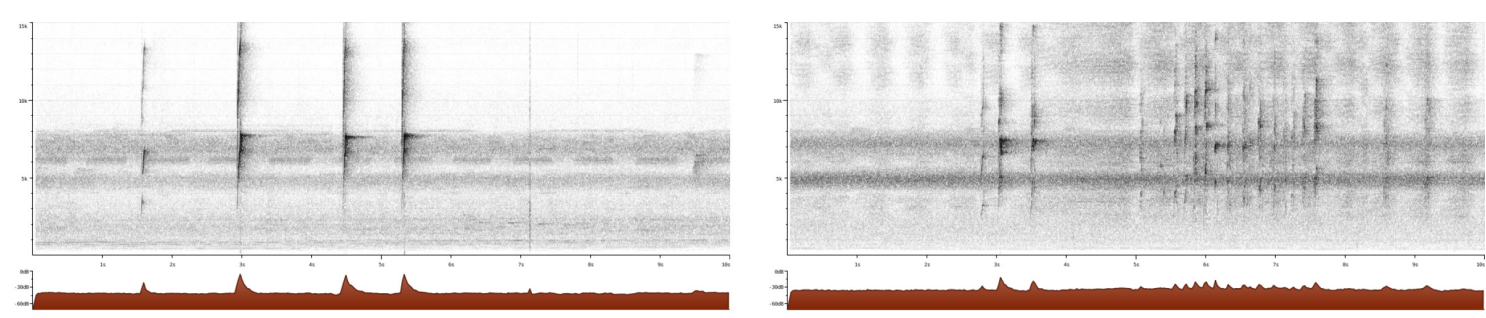

C
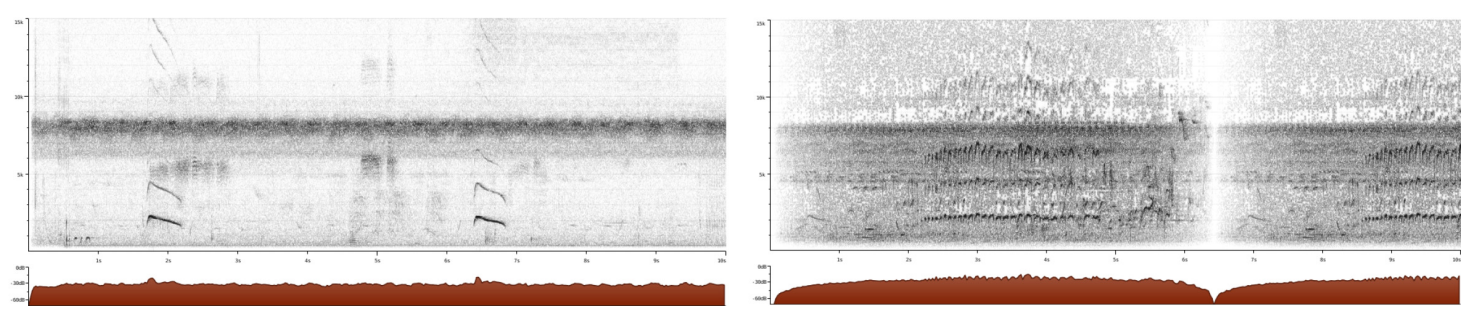

Figure 5: First records of three subspecies in Ecuador. a) Oxyura jamaicensis andina, Yaguarcocha and San Pablo, Imbabura Province (D. Chulde and E. Obando-Clavijo); b) Tolmomyias sulphurescens insignis, Sacha Lodge, Sucumbíos Province (D. Lane; XC 214585, XC 214587); Myiarchus swainsoni phaeonotus, Sacha Lodge, Sucumbíos Province (D. Lane; XC 257112, XC 214547). 


\section{*Warbling Vireo Vireo gilvus}

Pichincha Province, Jardín Botánico de Quito, 11 April 2017, R. Ahlman (photo).

A single bird was first heard calling and latter observed and photographed (Fig. 1d). It responded to playback of its own calls, initially audio-recorded, with a soft 'tchep' call and readily approached for photographs (Ahlman, 2017c). It also responded to playback of calls of the nominate $V . g$. gilvus subspecies from eastern North America, and not to the western subspecies (R. Ahlman, in litt., September 2019). Observations lasted from $7 \mathrm{~h} 45$ through $8 \mathrm{~h} 20$, when the bird flew south and was not seen again. This unexpected record is the first for Ecuador and South America, and the southernmost record of the species in the Neotropics (Ridgely \& Tudor, 2009; Brewer, 2018). Two unvouchered records from Venezuela are reported in eBird (Hernández-Vidal, 2000).

\section{Southern Martin Progne elegans}

Orellana Province, Tiputini, 29-31 August 2016, J. Nilsson.

Three adult males, two adult females, and one immature were observed flying and perched on a tall tower at Tiputini village, on the northern bank of the Río Napo. Although there are few records to date (Freile \& Restall, 2018), the species is possibly a regular annual visitor to Amazonian Ecuador. There is also a small wintering population at El Carmen de Putumayo, province of Sucumbíos, were first found by R. Ahlman in mid-May 2016 (Ahlman, 2016a). The paucity of records, however, makes it desirable to get additional reports in order to understand the species' status and seasonality in the country.

\section{Cliff Swallow Petrochelidon pyrrhonota}

Pichincha Province, Tababela (Quito) Airport pond, 21 September 2015, J. Nilsson (photo).

Two adult birds with chestnut fronts were observed, photographed and carefully studied while perching on the ground together with Barn Hirundo rustica, Bank Riparia riparia and Blue-and-white Pygochelidon cyanoleuca swallows, as well as a few individuals of $P$. pyrrhonota with white fronts. Dark chestnut/rufous forehead, similar in tone to throat and sides of head, was noticed in both individuals, and clearly separated them from other whitish/pale fronted individuals seen at the same site (most likely nominate subspecies); these pale-fronted birds were larger than the two chestnut-fronted individuals. One additional record of a chestnut-fronted $P$. pyrrhonota was obtained by R. Ahlman at Lago San Pablo on September 2018 (Ahlman, 2018a).

These birds might represent either subspecies $P$. pyrrhonota melanogaster, which is the subspecies to which chestnut-fronted birds seen in Ecuador have previously been assigned (Freile et al., 2013; 2017), or $P$. p . tachina since some individuals of this subspecies might show dark foreheads, yet somewhat paler than throat and sides of head (Sibley, 2014). Until specimens of chestnut-fronted birds are collected or larger series of photographs obtained, Ecuadorian records could not be assigned with certainty to subspecies $P$. p . melanogaster or $P$. $p$. tachina.

\section{Bicoloured Conebill Conirostrum bicolor}

Orellana Province, river island close to Ballesteros, 30 August 2016, J. Nilsson.

One pair was observed in a fairly young successional Cecropia stand on a small river island along the Río Napo. The birds were feeding in the subcanopy, often hanging upside down on the underside of Cecropia leaves. This is the third locality for the species in Ecuador, all confined to river islands in the Río Napo (Nilsson et al., 2014; Freile \& Restall, 2018).

\section{Red-breasted Meadowlark Sturnella militaris}

Napo Province, Vinillos, 30 April 2016, A. Solano-Ugalde.

One adult male was observed perching in low grasses and walking on the ground. Vinillos represents the highest elevation known in Ecuador, but the species is likely spreading following deforestation both in the northwest lowlands (Olmstead et al., 2011) and eastern Andean slopes (i.e., a small resident population exists in Borja, 18 $\mathrm{km}$ north of Vinillos). 


\section{Other records received}

The following records, received by CERO, do not represent major range extensions but add to our knowledge of bird distribution in Ecuador. One Eastern Kingbird Tyrannus tyrannus observed at Guango Lodge (28 April 2016; A. Solano-Ugalde) actively feeding from the top of bushes, sallying and chasing prey in forest edge [mostly found below $800 \mathrm{~m}$, fewer records in the inter-Andean valleys and scattered records along the Andean slopes; Ridgely \& Greenfield, 2001; Freile \& Restall, 2018]. One adult Curve-billed Tinamou Nothoprocta curvirostris was photographed at $4050 \mathrm{~m}$ a.s.l. along a trail beyond Teleférico de Quito, on mount Pichincha, 18 December 2016; X. Amigo). It was leisurely foraging among tussock grasses [mostly found below $3700 \mathrm{~m}$, but records up to 3900 m; Ridgely \& Greenfield, 2001; Freile \& Restall, 2018].

a

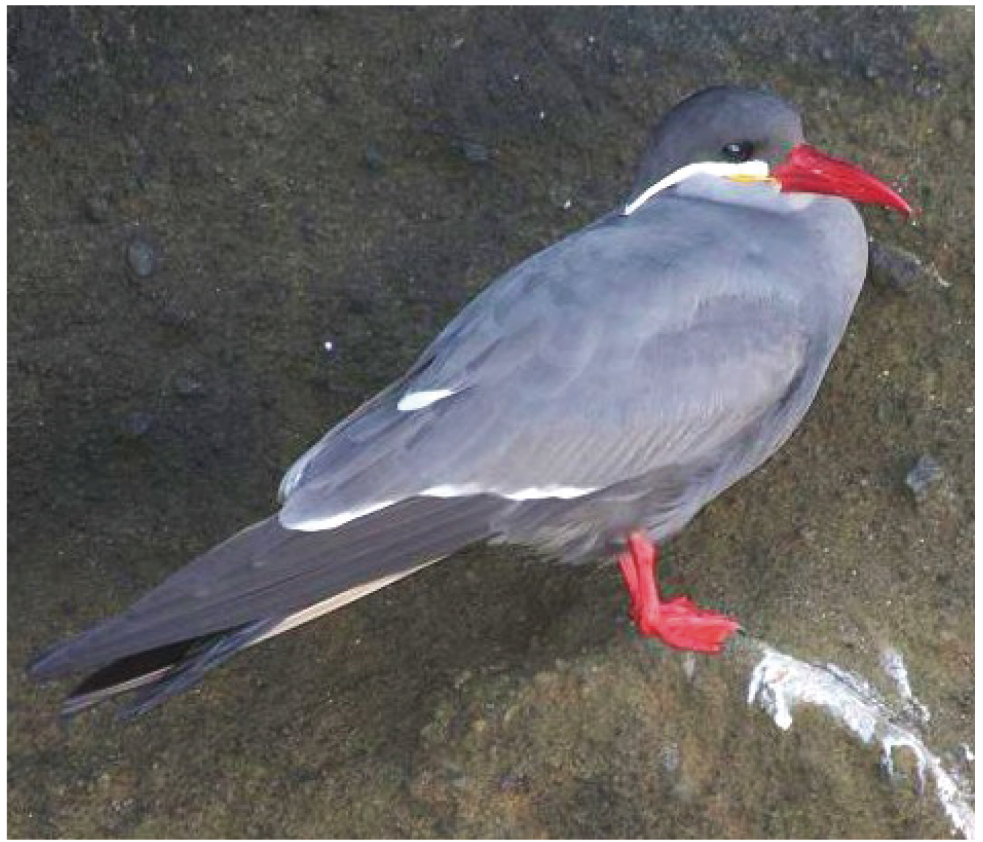

b

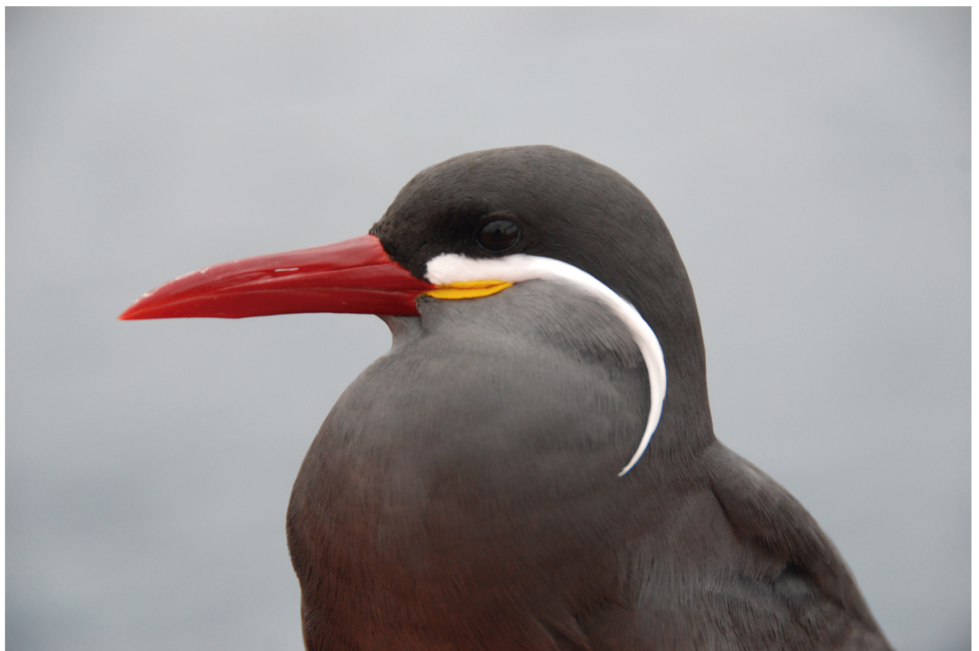

Figure 6: First records of Larosterna inca for the Galápagos Islands. a) Daphne Major (J. C. Manosalvas); b) Española (L. D. Dejean).

\section{Rejected records}

One record was rejected due to imprecise documentation (Black Swift Cypseloides niger). A tracking study of spring migration routes of three individuals of $C$. niger borealis carrying a geolocator showed that one individual passed through Amazonian Ecuador, in southeast direction to its wintering grounds in western Brazil (Beason et al., 2012). However, geolocators do not work with a global positioning system, but rather geolocate measuring light levels every minute. Given that the accuracy of latitude calculated by geolocators is not completely reliable near the equator, because day and night have equal duration, errors of up to 200 linear km are plausible (Beason 
et al., 2012). Consequently, the actual route of the tracked individual might have been elsewhere across the western Amazon, and we therefore reject this evidence as proof of its presence in the country.

\section{Invalidated records}

We found 39 species cited in different published sources (Chapman 1926; Orcés, 1944; Meyer de Schauensee, 1966; Ortiz-Crespo \& Valarezo-Delgado, 1975; Butler, 1979; Fjeldså \& Krabbe, 1990; Ortiz-Crespo et al., 1990; Restall et al., 2006; Byers, 2009; McMullan \& Navarrete, 2013; Moore et al., 2013) that do not occur within the current boundaries of mainland Ecuador and 6 additional species that do not occur within the Galápagos Archipelago (Ridgway, 1896; Harris, 1982; Vargas, 1996; Castro \& Phillips, 1996; Table 4). Also, we were aware of unpublished records from mainland Ecuador of four additional species that demanded validation. Tables 2, 3 and 5 present 43 species with dubious/invalid records, including cases of taxonomic updates, misidentifications, erroneous records, locality errors, and unjustified and/or unproven records for mainland Ecuador. Erroneous records discussed by Wiedenfeld (2006) for Galápagos are presented and discussed in Table 4. Several erroneous or outdated records already debated by Ridgely \& Greenfield (2001) are presented and discussed in Table 3.
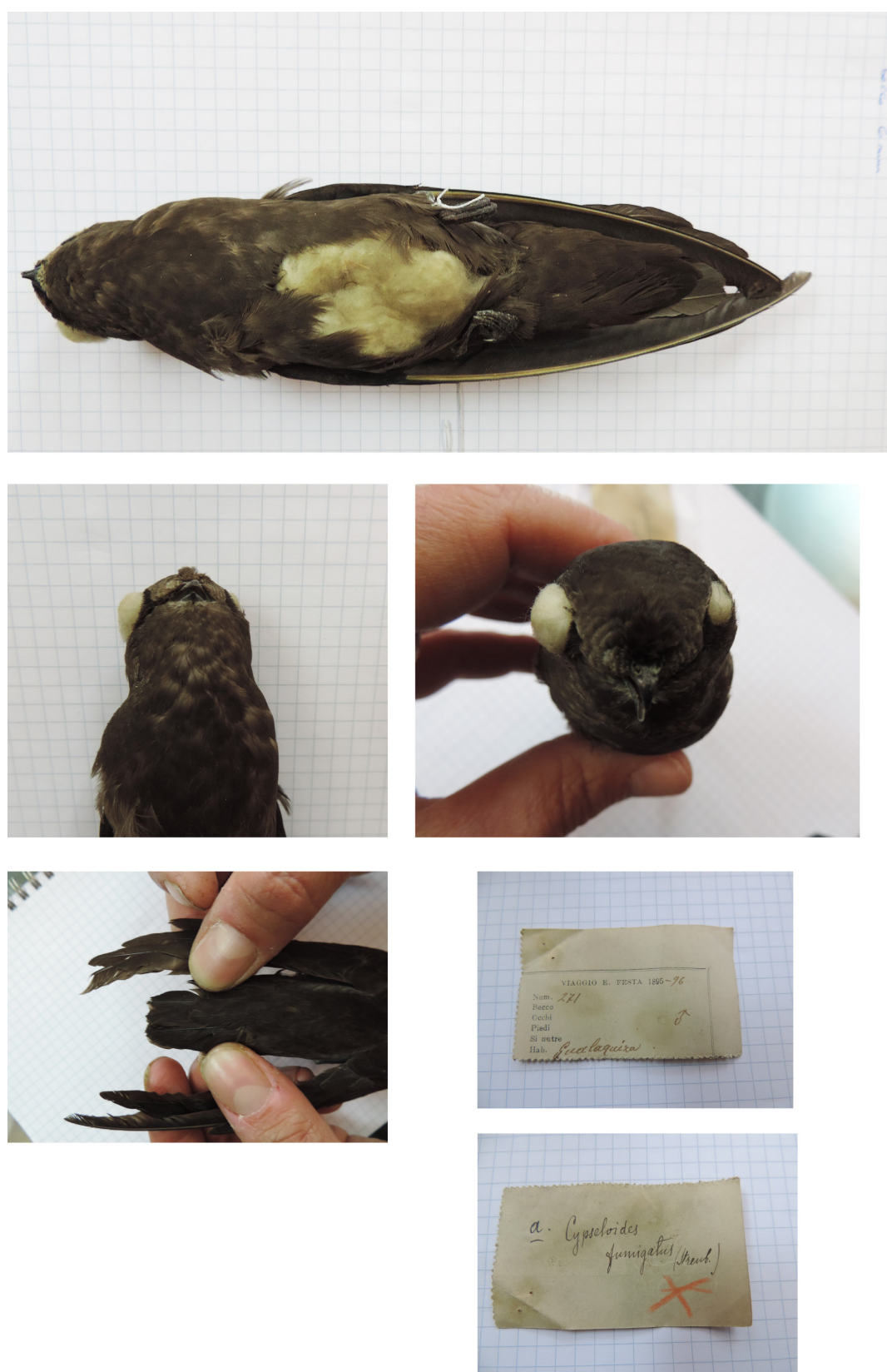

Figure 7: Specimens of Cypseloides cryptus collected at Gualaquiza, Morona Santiago Province, by E. Festa, and first identified as C. fumigatus (G. Soldato). 
Table 2: Erroneous citations for Ecuador in distribution texts and maps in Birds of northern South America (Restall et al., 2006).

\begin{tabular}{|c|c|c|c|c|}
\hline Species & Common name & $\begin{array}{l}\text { Ecuador } \\
\text { map }\end{array}$ & $\begin{array}{l}\text { Status in text } \\
\text { volume }\end{array}$ & CERO comment \\
\hline Mitu tomentosum & $\begin{array}{l}\text { Crestless } \\
\text { Curassow }\end{array}$ & $\begin{array}{l}\text { all } \\
\text { Amazon }\end{array}$ & - & No records; wrong citation. \\
\hline $\begin{array}{l}\text { Pterodroma } \\
\text { neglecta }\end{array}$ & $\begin{array}{l}\text { Kermadec } \\
\text { Petrel }\end{array}$ & $?$ & $\begin{array}{l}\text { possible vagrant } \\
\text { off-shore }\end{array}$ & No records; wrong citation. \\
\hline Fregetta tropica & $\begin{array}{l}\text { Black-bellied } \\
\text { Storm-petrel }\end{array}$ & $?$ & $\begin{array}{l}\text { rare vagrant off } \\
\text { Ecuador }\end{array}$ & No records; wrong citation. \\
\hline $\begin{array}{l}\text { Antrostomus } \\
\text { sericocaudatus }\end{array}$ & $\begin{array}{l}\text { Silky-tailed } \\
\text { Nightjar }\end{array}$ & $\begin{array}{l}\text { dot in S } \\
\text { Andes }\end{array}$ & $\begin{array}{l}\text { Subespecies } \\
\text { mengeli locally } \\
\text { common in Ecuador }\end{array}$ & No records; wrong citation. \\
\hline Coeligena violifer & $\begin{array}{l}\text { Violet-fronted } \\
\text { Starfronlet }\end{array}$ & $\begin{array}{l}\text { dot in S } \\
\text { Andes }\end{array}$ & $\begin{array}{l}\text { uncertain, possibly } \\
\text { rare }\end{array}$ & $\begin{array}{l}\text { Erroneously cited for S } \\
\text { Ecuador by Züchner } \\
\text { (1999). }\end{array}$ \\
\hline $\begin{array}{l}\text { Loddigesia } \\
\text { mirabilis }\end{array}$ & $\begin{array}{l}\text { Marvelous } \\
\text { Spatuletail }\end{array}$ & no map & $\begin{array}{l}\text { unconfirmed sight } \\
\text { record in Ecuador }\end{array}$ & No records; wrong citation. \\
\hline $\begin{array}{l}\text { Dendroplex } \\
\text { kienerii }\end{array}$ & $\begin{array}{l}\text { Zimmer's } \\
\text { Woodcreeper }\end{array}$ & $?$ & $\begin{array}{l}\text { uncertain, very } \\
\text { probably }\end{array}$ & $\begin{array}{l}\text { Not unlikely, but no } \\
\text { records to date. }\end{array}$ \\
\hline Formicivora rufa & $\begin{array}{l}\text { Rusty-backed } \\
\text { Antwren }\end{array}$ & $\begin{array}{l}\text { dot in S } \\
\text { Andes }\end{array}$ & - & Erroneous map. \\
\hline Pithys castaneus & $\begin{array}{l}\text { White-masked } \\
\text { Antbird }\end{array}$ & $\begin{array}{l}\text { dot in } \\
\text { extreme } \\
\text { SE }\end{array}$ & $\begin{array}{l}\text { hypothetical, one } \\
\text { sighting } \\
\text { unconfirmed }\end{array}$ & $\begin{array}{l}\text { Not unlikely, but no } \\
\text { records to date. }\end{array}$ \\
\hline $\begin{array}{l}\text { Mitrephanes } \\
\text { olivaceus }\end{array}$ & $\begin{array}{l}\text { Olive } \\
\text { Flycatcher }\end{array}$ & $\begin{array}{l}\text { ? and dot } \\
\text { in } \mathrm{S} \text { Andes }\end{array}$ & $\begin{array}{l}\text { A few unconfirmed } \\
\text { sight records }\end{array}$ & $\begin{array}{l}\text { Not unlikely, but no } \\
\text { records to date. }\end{array}$ \\
\hline $\begin{array}{l}\text { Tyrannus } \\
\text { forficatus }\end{array}$ & $\begin{array}{l}\text { Scissor-tailed } \\
\text { Flycatcher }\end{array}$ & $?$ & sight records & $\begin{array}{l}\text { Not unlikely, but no } \\
\text { records to date. }\end{array}$ \\
\hline Progne sinaloae & Sinaloa Martin & $?$ & $\begin{array}{l}\text { Unrecorded but } \\
\text { hypothetical }\end{array}$ & No records; wrong citation. \\
\hline
\end{tabular}

Table 3: Unvouchered, uncertain or erroneous records from continental Ecuador discussed in volume I (Status, distribution and taxonomy) of Ridgely \& Greenfield (2001).

\begin{tabular}{lllll}
\hline Species & Common name & Status vol. I & Original source & CERO comment \\
\hline $\begin{array}{l}\text { Phalacrocorax } \\
\text { gaimardi }\end{array}$ & $\begin{array}{l}\text { Red-legged } \\
\text { Cormorant }\end{array}$ & no evidence & $\begin{array}{l}\text { Enticott \& } \\
\text { Tipling (1997) }\end{array}$ & $\begin{array}{l}\text { Unsupported record } \\
\text { repeated in other } \\
\text { sources (Harrison, } \\
1985 ; 1987) .\end{array}$ \\
$\begin{array}{l}\text { Buteogallus } \\
\text { coronatus }\end{array}$ & $\begin{array}{l}\text { Chaco } \\
\text { (Crowned) Eagle }\end{array}$ & $\begin{array}{l}\text { erroneous old } \\
\text { citations }\end{array}$ & $\begin{array}{l}\text { Taczanowski \& } \\
\text { Berlepsch (1885) }\end{array}$ & $\begin{array}{l}\text { Misidentified } \\
\text { specimen; locality } \\
\text { (Rín Topo, } \\
\text { Tungurahua) is }\end{array}$
\end{tabular}




$\begin{array}{llll}\begin{array}{l}\text { Geranoaetus } \\ \text { albicaudatus }\end{array} & \text { White-tailed } & \begin{array}{l}\text { erroneous old } \\ \text { citations }\end{array} & \text { Chapman (1926) }\end{array}$

Rallus semiplumbeus

Bogota Rail

Forpus conspicillatus

Spectacled

Parrotlet

$\begin{array}{ll}\text { Pionites } & \text { White-bellied } \\ \text { leucogaster } & \text { Parrot }\end{array}$

Chlorostilbon stenurus

Amazilia edward

Snowy-bellied Hummingbird

Oxypogon guerini

Green-bearded Helmetcrest Pharomachrus
fulgidus

White-tipped Quetzal

Synallaxis
albescens

Clytoctantes alixi

Recurve-billed Bushbird

Slaty Gnateater Spinetail

Conopophaga ardesiaca misidentified

misidentified?

Fjeldså \& Krabbe (1990)

Salvadori \& Festa (1900)

Meyer de Schauensee (1966)

Oberholser (1902) citations

erroneous old citations

Oberholser (1902)

Fjeldså \& Krabbe (1990)

Meyer de Schauensee (1966)

erroneous old citations

old taxonomy misidentified very probably

accurate for Solitary

Eagle B. solitarius.

Misidentified

specimens, now

known to be Variable

Hawk G. polyosoma.

A misidentified juvenile Virginia Rail R. limicola aequatorialis.

An observation by Bloch, Poulsen, Rahbek \& Rasmussen [cited as 'certainly not coelestis'], but unlikely by distribution; locality is accurate for Pacific Parrotlet $F$. coelestis.

Unsupported record repeated in other sources.

Very probably a misidentified old specimen; very unlikely by distribution.

Very probably misidentified old specimens; very unlikely by distribution.

Uncorroborated sighting by J. C. Matheus; unlikely by distribution.

Unfounded error.

Formerly ranked as co-specific with Darkbreasted Spinetail $S$. albigularis.

An old error already

erroneous old citations

Chapman (1926)

discussed by Chapman (1926).

Available description of female specimen is

Chapman (1926) accurate for Ashthroated C. peruviana or Chestnut-crowned 


\begin{tabular}{lllll}
$\begin{array}{l}\text { Iridosornis } \\
\text { reinhardti }\end{array}$ & $\begin{array}{l}\text { Yellow-scarfed } \\
\text { Tanager }\end{array}$ & $\begin{array}{l}\text { very probably } \\
\text { misidentified }\end{array}$ & $\begin{array}{l}\text { Bloch } \text { et al. } \\
(1991)\end{array}$ & $\begin{array}{l}\text { Very probably } \\
\text { misidentified; } \\
\text { observers were not } \\
100 \% \text { convinced. }\end{array}$ \\
\hline
\end{tabular}

Table 4: Unvouchered, uncertain or erroneous records in Galápagos Islands discussed by Wiedenfeld (2006).

\begin{tabular}{|c|c|c|c|c|}
\hline Species & $\begin{array}{l}\text { Common } \\
\text { name }\end{array}$ & $\begin{array}{l}\text { Status in } \\
\text { Wiedenfeld }\end{array}$ & $\begin{array}{l}\text { Original } \\
\text { source }\end{array}$ & CERO comment \\
\hline $\begin{array}{l}\text { Thalassarche } \\
\text { melanophris }\end{array}$ & $\begin{array}{l}\text { Black-browed } \\
\text { Albatross }\end{array}$ & no evidence & $\begin{array}{l}\text { Castro \& } \\
\text { Phillips (1996) }\end{array}$ & $\begin{array}{l}\text { Record not supported in } \\
\text { earlier literature or } \\
\text { sightings. }\end{array}$ \\
\hline $\begin{array}{l}\text { Fulmarus } \\
\text { glacialoides }\end{array}$ & $\begin{array}{l}\text { Southern } \\
\text { Fulmar }\end{array}$ & no evidence & $\begin{array}{l}\text { Castro \& } \\
\text { Phillips (1996) }\end{array}$ & $\begin{array}{l}\text { Record not supported in } \\
\text { earlier literature or } \\
\text { sightings. }\end{array}$ \\
\hline $\begin{array}{l}\text { Numenius } \\
\text { borealis }\end{array}$ & $\begin{array}{l}\text { Eskimo } \\
\text { Curlew }\end{array}$ & $\begin{array}{l}\text { erroneous old } \\
\text { citations }\end{array}$ & $\begin{array}{l}\text { Ridgway } \\
\text { (1896) }\end{array}$ & $\begin{array}{l}\text { Ridgway (1896) apparently } \\
\text { cited a record by Salvin } \\
\text { (1876). Rothschild et al. } \\
\text { (1899) re-identified the } \\
\text { specimen as } N . \text { phaeopus. }\end{array}$ \\
\hline $\begin{array}{l}\text { Coccyzus } \\
\text { lansbergi }\end{array}$ & $\begin{array}{l}\text { Grey-capped } \\
\text { Cuckoo }\end{array}$ & misidentified? & $\begin{array}{l}\text { Ridgely \& } \\
\text { Greenfield } \\
\text { (2001) }\end{array}$ & $\begin{array}{l}\text { Ridgely \& Greenfield } \\
\text { (2001) indicate vagrant } \\
\text { records from Galápagos } \\
\text { with no further information; } \\
\text { no records to date. }\end{array}$ \\
\hline $\begin{array}{l}\text { Crotophaga } \\
\text { sulcirostris }\end{array}$ & $\begin{array}{l}\text { Groove-billed } \\
\text { Ani }\end{array}$ & misidentified? & $\begin{array}{l}\text { Harris (1973, } \\
\text { 1981, 1982; } \\
\text { Swash \& Still } \\
(2000)\end{array}$ & $\begin{array}{l}\text { No documentation available } \\
\text { to date. Harris (1981) } \\
\text { reported this species, but not } \\
\text { Smooth-billed Ani } C \text {. ani; } \\
\text { then Harris (1982) reported } \\
\text { both species. Only C. ani is } \\
\text { definitely known from } \\
\text { Galápagos, specimens } \\
\text { dating back to } 1985 \text {. } \\
\text { Misidentification most } \\
\text { likely; see Wiedenfeld } \\
\text { (2006) for further } \\
\text { discussion. }\end{array}$ \\
\hline $\begin{array}{l}\text { Psittacara } \\
\text { erythrogenys }\end{array}$ & $\begin{array}{l}\text { Red-masked } \\
\text { Parakeet }\end{array}$ & introduced? & Vargas (1996) & $\begin{array}{l}\text { One seen in } 1996 \text { (San } \\
\text { Cristóbal), but not } \\
\text { established as feral; sighting } \\
\text { likely was an escaped pet } \\
\text { that perished. }\end{array}$ \\
\hline
\end{tabular}


Table 5: Unsupported and erroneous records cited in published literature; four unpublished records reported to CERO by authors or third parties are also discussed.

\begin{tabular}{|c|c|c|c|}
\hline Species & Common name & Source & CERO comment \\
\hline Mitu tomentosum & $\begin{array}{l}\text { Crestless } \\
\text { Curassow }\end{array}$ & Butler (1979) & $\begin{array}{l}\text { This author presents a list of } \\
\text { hypothetical and accidental species, } \\
\text { but fails to explain his definition of } \\
\text { hypothetical, or to provide } \\
\text { reasoning or documentation for } \\
\text { those putative records. There are no } \\
\text { records of this species in Ecuador. }\end{array}$ \\
\hline $\begin{array}{l}\text { Penelope } \\
\text { albipennis }\end{array}$ & $\begin{array}{l}\text { White-winged } \\
\text { Guan }\end{array}$ & Chapman (1926) & $\begin{array}{l}\text { No recent or historical records, } \\
\text { though Chapman (1926) included it } \\
\text { in his book, with "Tumbez" as the } \\
\text { collecting locality. In Chapman's } \\
\text { days, "Tumbez" referred to a } \\
\text { Peruvian locality. Curiously, } \\
\text { Chapman's maps do not indicate } \\
\text { country boundaries. }\end{array}$ \\
\hline
\end{tabular}

$\begin{array}{ll}\text { Penelope argyrotis } & \text { Band-tailed } \\ \text { Guan }\end{array}$

Pelecanus erythrorhynchos

Cypseloides fumigatus

\begin{abstract}
Amazilia
\end{abstract} saucerottei

Malacoptila rufa

Rufous-necked Puffbird

Steely-vented Hummingbird

American White Pelican

Sooty Swift

$$
\begin{aligned}
& \text { Chapman (1926) and } \\
& \text { others }
\end{aligned}
$$

\section{Brotogeris} jugularis
Orange-chinned Parakeet
Butler (1979) Valarezo-Delgado (1975), Butler (1979)

Unpublished, unvouchered and undocumented observation not yet reported to CERO

Butler (1979)

Formerly, Bearded Guan P. barbata was ranked as a subspecies of Bandtailed Guan $P$. argyrotis. These authors cite Chapman (1926) as source of records of $P$. argyrotis and erroneously included both species in the country list. However, Chapman gives species status to $P$. barbata and does not include $P$. argyrotis in his book.

Single bird observed by R. Jonsson at Same, Esmeraldas (unknown date), no further details or supporting evidence.

A specimen collected at Gualaquiza by E. Festa was relocated by G. Soldato at the Torino Museum (Fig. 7), and re-identified as Whitechinned C. cryptus by CERO.

Included in a list of hypothetical and accidental species, with no reasoning or documentation. There are no records of this species in Ecuador.

Included in a list of hypothetical and accidental species, with no reasoning or documentation. There are no records of this species in Ecuador.

Chapman (1926) and others
Supposedly collected at Napo and Canelos; more likely represent 


$\begin{array}{lll}\text { Pteroglossus } & \text { Brown- } & \text { Orcés (1944), Ortiz- } \\ \text { mariae } & \text { mandibled } & \text { Crespo \& Valarezo- } \\ & \text { Araçari } & \text { Delgado (1975) }\end{array}$

$\begin{array}{ll}\begin{array}{l}\text { Cranioleuca } \\ \text { vulpina }\end{array} & \begin{array}{l}\text { Rusty-backed } \\ \text { Spinetail }\end{array}\end{array}$

Certhiaxis

cinnamomeus

Yellow-chinned

Spinetail

Hylopezus dives

Thicket Antpitta

Moore et al. (2013)
Cobalt-winged Parakeet $B$. cyanoptera. No further justification.

Orcés suggested that some specimens of Ivory-billed Araçari $P$. azara were possibly hybrids with 'Brown-mandibled' Araçari $P$. mariae or individual variation in $P$. azara; $P$. mariae is no longer ranked as valid species (Remsen $e t$ al., 2018).

Included in a list of hypothetical and accidental species, with no reasoning or documentation. There are no records of this species in Ecuador.

Inexplicably included in this recent publication; no documentation or reasoning support this record. Most likely a slip by the author.

A single recording reportedly obtained at Charco Vicente, on a trail to Cascada San Miguel, province of Esmeraldas. Despite intensive surveying effort for 9 years at nearby Playa de Oro, that included a few visits to Charco Vicente, the species was not located by Jahn (2011). Subsequent searches using intensive playback in appropriate habitat for the species at Playa de Oro (very dense thickets of scrubby vegetation at forest borders) by CERO members and other observers have been unsuccessful, even though this species readily responds to playback throughout its range. Habitat reported for the sound recording from Charco Vicente (inside primary forest) is unexpected for the species. Until further evidence is obtained, CERO invalidates this record, which was also dismissed by Greeney (2018).

$\begin{array}{lll}\begin{array}{l}\text { Gymnocichla } \\ \text { nudiceps }\end{array} & \text { Bare-crowned } & \text { Butler (1979) } \\ & \text { Antbird } & \end{array}$

$\begin{array}{ll}\text { Pygochelidon } & \text { Black-collared } \\ \text { melanoleuca } & \text { Swallow }\end{array}$

Ortiz-Crespo \& Valarezo-Delgado (1975), Butler (1979)

Included in the main checklist without explanation or documentation. No records in Ecuador.

First authors cite a personal communication by G. T. CorleySmith to G. Orcés, but there is no further documentation and no records known to CERO.

No specimens from Ecuador mentioned in the description (O’Neill et al., 2011); not unlikely, 


\begin{tabular}{|c|c|c|c|}
\hline $\begin{array}{l}\text { Catharus } \\
\text { fuscescens }\end{array}$ & Veery & $\begin{array}{l}\text { Unpublished, } \\
\text { unvouchered and } \\
\text { undocumented } \\
\text { observations not yet } \\
\text { reported to CERO }\end{array}$ & $\begin{array}{l}\text { A recent sighting by B. Herrera } \\
\text { from Valladolid, Zamora Chinchipe } \\
\text { (early 2011) without further details } \\
\text { or documentation. Another } \\
\text { unvouchered observation from } \\
\text { Wildsumaco, Napo (September } \\
\text { 2013; fide R. Ahlman). Until further } \\
\text { evidence is obtained, the species } \\
\text { could not be included in the country } \\
\text { checklist. }\end{array}$ \\
\hline $\begin{array}{l}\text { Dumetella } \\
\text { carolinensis }\end{array}$ & Grey Catbird & $\begin{array}{l}\text { Unpublished, } \\
\text { unvouchered and } \\
\text { undocumented } \\
\text { observations not yet } \\
\text { reported to CERO }\end{array}$ & $\begin{array}{l}\text { One observation by R. Jonsson at } \\
\text { Mindo, Pichincha (no date). Until } \\
\text { further evidence is obtained, the } \\
\text { species could not be included in the } \\
\text { country checklist. }\end{array}$ \\
\hline Tangara varia & Dotted Tanager & $\begin{array}{l}\text { Unpublished, } \\
\text { unvouchered and } \\
\text { undocumented } \\
\text { observation not yet } \\
\text { reported to CERO }\end{array}$ & $\begin{array}{l}\text { A sighting by B. Herrera at Zamora } \\
\text { (March 2011), without further } \\
\text { details or documentation. Until } \\
\text { further evidence is obtained, the } \\
\text { species could not be included in the } \\
\text { country checklist. }\end{array}$ \\
\hline
\end{tabular}

\section{ACKNOWLEDGMENTS}

We thank all observers who submitted their records to CERO (see under species accounts), and to R. Ahlman, B. Haase, M. Tellkamp, T. Lilley, K. Frost, A. Jaramillo, J. Megyesi, and P. Bourdin for uploading lists to eBird or sharing their remarkable records with us. Thanks to external advisory on some species identification provided by N. Krabbe, D. F. Lane, A. Jaramillo, R. Ahlman and B. Haase, and to our newest CERO board members for additional input (S. Olmstead, N. Athanas, and M. Sánchez-Nivicela). Thanks to our institutions and tour operators for allowing us to take regular field trips. Special thanks to G. Soldato for relocating an Ecuadorian specimen of a Cypseloides swift in the Torino Museum. Comments by R. Ahlman and H. F. Greeney greatly improved this manuscript.

\section{REFERENCES}

Ahlman, R. (2016, May 16). eBird checklist: https://ebird.org/view/checklist/S29720198. eBird: an online database of bird distribution and abundance. Ithaca, New York. URL: https://ebird.org

Ahlman, R. (2016, October 03). eBird checklist: https:/ebird.org/view/checklist/S31870827. eBird: an online database of bird distribution and abundance. Ithaca, New York. URL: https://ebird.org

Ahlman, R. (2017, January 17). eBird checklist: https://ebird.org/view/checklist/S33878771. eBird: an online database of bird distribution and abundance. Ithaca, New York. URL: https://ebird.org

Ahlman, R. (2017, April 4). eBird checklist: https:/ebird.org/view/checklist/S35696806. eBird: an online database of bird distribution and abundance. Ithaca, New York. URL: https://ebird.org

Ahlman, R. (2017, April 11). eBird checklist: https://ebird.org/view/checklist/S35871298. eBird: an online database of bird distribution and abundance. Ithaca, New York. URL: https://ebird.org

Ahlman, R. (2017, November 20). eBird checklist: https://ebird.org/view/checklist/S40619789. eBird: an online database of bird distribution and abundance. Ithaca, New York. URL: https://ebird.org 
Ahlman, R. (2018, June 28). eBird checklist: https://ebird.org/view/checklist/S46856747. eBird: an online database of bird distribution and abundance. Ithaca, New York. URL: https://ebird.org

Ahlman, R. (2018, September 24). eBird checklist: https://ebird.org/view/checklist/S48714788. eBird: an online database of bird distribution and abundance. Ithaca, New York. URL: https://ebird.org

Beason, J.P., Gunn, C., Potter, K.M., Sparks, R.A. \& Fox, J.W. (2012). The northern Black Swift: migration path and wintering area revealed. Auk, 124, 1-8. DOI: https://doi.org/10.1676/11-146.1

Bloch, H., Poulsen, M.K., Rahbek, C. \& Rasmussen, J.F. (1991). A survey of the montane forest avifauna of the Loja province, southern Ecuador. Cambridge, UK: International Council for Bird Preservation.

Brewer, D. (2018, July 22). Warbling Vireo (Vireo gilvus). In: del Hoyo, J., Elliott, A., Sargatal, J., Christie, D.A. \& de Juana, E. (Eds.), Handbook of the birds of the world alive. Barcelona, Spain: Lynx Edicions. URL: https://www.hbw.com/node/61263

Brinkhuizen, D.M. (2014). XC 206291 Ash-throated Crake, Mustelirallus albicollis. Xeno-Canto. URL: www.xeno-canto.org/206291.

Butler, T.Y. (1979). A checklist of the birds of the mainland Ecuador. Durham, New Hampshire: Ramphastos Agency.

Byers, C. (2009). A photographic guide to birds of Ecuador and Galapagos. London, UK: New Holland Publishers.

Campbell, O. (2018). First documented record of Ruff Calidris pugnax in Ecuador. Cotinga, 40, 97-98.

Castro, I. \& Phillips, A. (1996). A guide to the birds of the Galapagos Islands. London, UK: Christopher Helm.

Clements, J.F., Schulenberg, T.S., Iliff, M.J., Roberson, D., Fredericks, T.A., Sullivan, B.L. \& Wood, C.L. (2017, March 20). The eBird/Clements checklist of birds of the world: v2017. Ithaca, New York: Cornell Lab of Ornithology. URL: http://www.birds.cornell.edu/clementschecklist/download/IOC

Chapman, F.M. (1926). The distribution of bird-life in Ecuador. Bulletin of the American Museum of Natural History, 55, 1-784. URL: http://digitallibrary.amnh.org/handle/2246/1244

Crochet, P.A., Lebreton, J.D. \& Bonhomme, F. (2002). Systematics of large white-headed gulls: patterns of mitochondrial DNA variation in western European taxa. Auk, 119, 603-620. DOI: https://doi.org/10.1642/00048038(2002)119[0603:SOLWHG]2.0.CO;2

Davies, I., Sullivan, B. \& Barry, J. (2016). Rich media = rich data: a new frontier for ornithology in the Neotropics and beyond. Neotropical Birding, 19, 28-32.

Donegan, T., Quevedo, A., Verhelst, J.C., Cortés-Herrera, O., Ellery, T. \& Salaman, P. (2015). Revision of the status of bird species occurring or reported in Colombia 2015, with discussion of BirdLife International's new taxonomy. Conservación Colombiana, 23, 3-48. URL: http://www.proaves.org/wpcontent/uploads/2015/12/Listado-y-Splits-Conservacion-Colombiana-23-3-48.pdf

eBird. (2018). eBird: an online database of bird distribution and abundance. Ithaca, New York: Cornell Lab of Ornithology. URL: https://ebird.org

Enticott, J. \& Tipling, D. (1997). A photographic handbook of the seabirds of the world. London, UK: New Holland Limited. 
Fitzpatrick, J.W., Bates, J.M., Bostwick, K.S., Caballero, I.C., Clock, B.M., Farnsworth, A., Hosner, P.A., Joseph, L., Langham, G.M., Lebbin, D.J., Mobley, J.A., Robbins, M.B., Scholes, E., Tello, J.G., Walther, B.A. \& Zimmer, K.J. (2004). Species accounts of Tyrannidae. In: del Hoyo, J., Elliott, A. \& Christie, D.A. (Eds.), Handbook of the birds of the world, vol. 9: cotingas to pipits and wagtails. (pp. 259-462). Barcelona, Spain: Lynx Edicions.

Fjeldså, J. (1986). Color variation in the Ruddy Duck (Oxyura jamaicensis andina). Wilson Bulletin, 98, 592593. URL: https://sora.unm.edu/sites/default/files/journals/wilson/v098n04/p0592-p0594.pdf

Fjeldså, J. \& Krabbe, N. (1990). Birds of the high Andes. Copenhagen, Denmark: Apollo Books \& University of Copenhagen.

Freile, J.F. \& Restall, R. (2018). Birds of Ecuador. London, UK: Helm Field Guides.

Freile, J.F., Brinkhuizen, D.M., Solano-Ugalde, A., Greenfield, P.J., Ahlman, R., Navarrete, L. \& Ridgely, R.S. (2013). Rare birds in Ecuador: first annual report of the Committee of Ecuadorian Records in Ornithology (CERO). Revista Avances, 5, B24-B41. DOI: http://dx.doi.org/10.18272/aci.v5i2.135

Freile, J.F., Solano-Ugalde, A., Brinkhuizen, D.M., Greenfield, P.J., Lysinger, M., Nilsson, J., Navarrete, L. \& Ridgely, R.S. (2017). Rare birds in Ecuador: third report of the Committee for Ecuadorian Records in Ornithology (CERO). Revista Ecuatoriana de Ornitología, 2, 8-27. DOI: http://dx.doi.org/10.18272/reo.v0i1.446

Freile, J.F., Brinkhuizen, D.M., Greenfield, P.J., Lysinger, M., Navarrete, L., Nilsson, J., Ridgely, R.S., SolanoUgalde, A., Ahlman, R. \& Boyla, K.A. (2018, April 10). Lista oficial de las aves del Ecuador. Quito, Ecuador: Comité Ecuatoriano de Registros Ornitológicos. URL: http://www.ceroecuador.wordpress.com

Frost, K. (2017, November 13). eBird checklist: https://ebird.org/view/checklist/S42597818. eBird: an online database of bird distribution and abundance. Ithaca, New York. URL: https://ebird.org

Greeney, H.F. (2018). Antpittas and gnateaters. London, UK: Helm Field Guides.

Haase, B. (2011). Aves marinas de Ecuador continental y acuáticas de las piscinas artificiales de Ecuasal. Guayaquil, Ecuador: Aves \& Conservación, BirdLife International \& Ecuasal S.A.

Harris, M.P. (1973). The Galápagos avifauna. Condor, 75, 265-278. URL: https://sora.unm.edu/sites/default/files/journals/condor/v075n03/p0265-p0278.pdf

Harris, M.P. (1981). La avifauna de Galápagos. In: Eberhardt, U. (Ed.), Compendio de ciencia en Galápagos. (pp. 261-282). Puerto Ayora, Ecuador: Charles Darwin Research Station.

Harris, M.P. (1982). The Collins field guide to the birds of Galapagos, 2nd ed. Lexington, Massachusetts: Stephen Greene Press.

Harrison, P. (1985). Seabirds: an identification guide. Boston, Massachusetts: Houghton Mifflin Company.

Harrison, P. (1987). Seabirds of the world: a photographic guide. London, UK: Christopher Helm.

Hernández-Vidal, M. (2000, June 4). eBird checklist: https://ebird.org/view/checklist/S32009732. eBird: an online database of bird distribution and abundance. Ithaca, New York. URL: https://ebird.org

del Hoyo, J., Collar, N. \& Kirwan, G.M. (2018, March 18). Andean Duck (Oxyura ferruginea). In: del Hoyo, J., Elliott, A., Sargatal, J., Christie, D.A. \& de Juana, E. (Eds.), Handbook of the birds of the world alive. Barcelona, Spain: Lynx Edicions. URL: https://www.hbw.com/node/467111 
Howell, S.N.G. (1994). Magnificent and Great frigatebirds in the eastern Pacific: a new look at an old problem. Birding, December 1994, 400-415.

Howell, S.N.G. \& Dunn, J. (2007). A reference guide to gulls of the Americas. Boston, Massachusetts: Houghton Mifflin Company.

Jahn, O. (2011). Bird communities of the Ecuadorian Choco: a case study in conservation. Bonn, Germany: Bonner Zoologische Monographien 56.

Jaramillo, A. (2008, July 20). eBird checklist: https://ebird.org/view/checklist/S11093495. eBird: an online database of bird distribution and abundance. Ithaca, New York. URL: https://ebird.org

Jiménez-Gonzales, K. (2018, April 10). eBird checklist: https://ebird.org/peru/view/checklist/S27828605. eBird: an online database of bird distribution and abundance. Ithaca, New York. URL: https://ebird.org

Jiménez-Uzcátegui, G. \& Manosalvas, J.C. (2010). First records of Inca Tern Larosterna inca in Galapagos Islands. Brenesia, 73-74, 137. URL: http://biblioteca.museocostarica.go.cr /articulo. aspx? $\mathrm{id}=6380 \&$ art $=3606112$

Lane, D. (2010). XC 257112 Yellow-olive Flycatcher, Tolmomyias sulphurescens. Xeno-Canto. URLs: https://www.xeno-canto.org/257112, https://www.xeno-canto.org/257113

Lane, D. (2015a). XC 214585, 214587 Yellow-olive Flycatcher, Tolmomyias sulphurescens. Xeno-Canto. URLs: https://www.xeno-canto.org/214585; https://www.xeno-canto.org/214587.

Lane, D. (2015b). XC 214547 Swainson's Flycatcher, Myiarchus swainsoni. Xeno-Canto. URL: https://www.xeno-canto.org/214547.

Lilley, T. (2019, Jul 01). eBird checklist: https://ebird.org/view/checklist/S57845101. eBird: an online database of bird distribution and abundance. Ithaca, New York: URL: https://ebird.org

Livezey, B.C. (1995). Phylogeny and comparative ecology of stiff-tailed ducks (Anatidae: Oxyurini). Wilson Bulletin, 107, 214-234. URL: https://sora.unm.edu/sites/default/files/journals/wilson/v107n02/p0214p0234.pdf

Loaiza, J.M., Crespo, J.C., Boas, A. \& Molina, P. (2019). First record Moustached Puffbird Malacoptila mystacalis (Bucconidae) in Ecuador. Revista Ecuatoriana de Ornitología, 5, 30-35.

Lysinger, M. (1995). XC 260956, 260957 Swainson's Flycatcher, Myiarchus swainsoni. Xeno-Canto. URLs: https://www.xeno-canto.org/260956, https://www.xeno-canto.org/260957.

Madge, S. \& Burn, H. (1988). Waterfowl, an identification guide to the ducks, geese and swans of the world. Boston, Massachusetts: Houghton Mifflin Company.

Martínez A., D. \& Gastezzi A., P. (2014). Registros nuevos de la distribución del canclón (Anhima cornuta) en el suroeste tropical de Ecuador. Ornitología Colombiana, 14, 125-129. URL: http://asociacioncolombianadeornitologia.org/wp-content/uploads/2014/12/MS1213.pdf

McCracken, K.G. \& Sorenson, M.D. (2005). Is homoplasy or lineage sorting the source of incongruent mtDNA and nuclear gene trees in stiff-tailed ducks (Nomonyx-Oxyura)? Systematic Biology, 54, 35-55. DOI: https://doi.org/10.1080/10635150590910249

McMullan, M. \& Donegan, T. (2014). Field guide to the birds of Colombia, second edition. Bogotá, Colombia: Fundación ProAves.

McMullan, M. \& Navarrete, L. (2013). Fieldbook of the birds of Ecuador, including the Galapagos islands. Quito, Ecuador: Fundación Jocotoco. 
McMullan, M. \& Navarrete, L. (2017). Fieldbook of the birds of Ecuador, including the Galapagos islands and common mammals. Quito, Ecuador: Partners for International Birding \& Ratty Ediciones.

Megyesi, J. (2015, October 18). eBird checklist: https:/ebird.org/view/checklist/S25469615. eBird: an online database of bird distribution and abundance. Ithaca, New York. URL: https://ebird.org

Mena V., P. \& Jahn, O. (2003). First record of the Whistling Heron Syrigma sibilatrix for Ecuador. Bulletin of the British Ornithologists Club, 123, 285-287. URL: https://www.biodiversitylibrary.org /item/124973\#page/325/mode/1up

Meyer de Schauensee, R. (1966). The species of birds of South America with their distribution. Narberth, Pennsylvania: Livingston Publishing.

Moore, J.V. (2005). XC 258958 Swainson's Flycatcher, Myiarchus swainsoni. Xeno-Canto. URL: https://www.xeno-canto.org/258958.

Moore, J.V., Krabbe, N. \& Jahn, O. (2013). Bird sounds of Ecuador, a comprehensive collection. San Jose, California: John V. Moore Nature Recordings.

Muñoz-Fuentes, V., Cortázar-Chinarro, M., Lozano, M. \& McCracken, K.G. (2013). Stepwise colonization of the Andes by Ruddy Ducks and the evolution of novel $\beta$-globin variants. Molecular Ecology, 22, 1231-1249. DOI: https://doi.org/10.1111/mec.12151

Nilsson, J., Freile, J.F., Ahlman, R., Brinkhuizen, D.M., Greenfield, P.J., \& Solano-Ugalde, A. (2014). Rare birds in Ecuador: second annual report of the Committee for Ecuadorian Records in Ornithology (CERO). Revista Avances, 6, B38-B50. DOI: http://dx.doi.org/10.18272/aci.v6i2.178

Oberholser, H.C. (1902). Catalogue of a collection of hummingbirds from Ecuador and Colombia. Proceedings of the U.S. National Museum, 24, 309-342. URL:

https://www.biodiversitylibrary.org/page/15782163\#page/383/mode/1up

Olmstead, S.T., Solano-Ugalde, A. \& Cisneros-Heredia, D.F. (2011). Range expansion of Red-breasted Blackbird Sturnella militaris in western Ecuador and notes on its contact zone with Peruvian Meadowlark $S$. bellicosa. Cotinga, 33, 80-83.

O’Neill, J.P., Lane, D.F. \& Naka, L.N. (2011). A cryptic new species of thrush (Turdidae: Turdus) from western Amazonia. Condor, 113, 869-880. DOI: https://doi.org/10.1525/cond.2011.100244

Orcés, G. (1944). Notas sobre la distribución geográfica de algunas aves Neotrópicas. Flora, 4, 103-123.

Ortiz-Crespo, F. \& Valarezo-Delgado, S. (1975). Lista de aves del Ecuador. Quito, Ecuador: Publicación de la Sociedad Ecuatoriana Francisco Campos de Amigos de la Naturaleza 2.

Ortiz-Crespo, F., Greenfield, P. \& Matheus, J.C. (1990). Aves del Ecuador, continente y archipiélago de Galápagos. Quito, Ecuador: FEPROTUR.

Remsen, J.V., Areta, J.I., Cadena, C.D., Jaramillo, A., Nores, M., Pacheco, J.F., Pérez-Emán, J., Robbins, M.B., Stiles, F.G., Stotz, D.F. \& Zimmer, K.J. (2018, February 28). A classification of the bird species of South America. American Ornithologists' Union. URL: http://www.museum.lsu.edu/ Remsen/SACCBaseline.html

Restall, R., Rodner, C. \& Lentino, M. (2006). Birds of northern South America. London, UK: Helm Field Guides.

Ridgely, R.S. \& Greenfield, P.J. (2001). The birds of Ecuador. Ithaca, New York: Cornell University Press. 
Ridgely, R.S. \& Greenfield, P.J. (2006). Aves del Ecuador. Quito, Ecuador: Academia de Ciencias de Filadelfia \& Fundación Jocotoco.

Ridgely, R.S. \& Tudor, G. (2009). Birds of South America. Passerines. London, UK: Helm Field Guides.

Ridgely, R.S., Greenfield, P.J. \& Guerrero, M. (1998). Una lista anotada de las aves del Ecuador continental. Quito, Ecuador: Fundación Ornitológica del Ecuador.

Ridgway, R. (1896). Birds of the Galapagos Archipelago. Proceedings of the U.S. National Museum, 19, 459670 .

Robbins, M.B. \& Ridgely, R.S. (1991). Sipia rosenbergi (Formicariidae) is a synonym of Myrmeciza (laemosticta) nigricauda, with comments on the validity of the genus Sipia. Bulletin of the British Ornithologists Club, 111, 11-18. URL: https://www.biodiversitylibrary.org/page/40027468\#page/19/mode/1up

Rothschild, W., Hartert, E. \& Jordan, K. (1899). A review of the ornithology of the Galapagos Islands with notes on the Webster-Harris Expedition. Novitates Zoologicae, 6, 85-286. URL: https://www.biodiversitylibrary.org/item/22632\#page/99/mode/1up

Salvin, O. (1876). On the avifauna of the Galápagos Archipelago. Transactions of the Zoological Society of London, 9, 447-510. URL: https://www.biodiversitylibrary.org/item/91779\#page/623/mode/1up

Salvadori, T. \& Festa, E. (1900). Viaggo del Dr. Enrico Festa nell'Ecuador. XII: Uccelli. Parte terza-TrochiliTinami. Bolletino dei Musei di Zoologia ed Anatomia Comparata della Reale Universita di Torino, 15, 1-54.

Schulenberg, T.S. \& Parker, T.A. (1997). A new species of tyrant-flycatcher (Tyrannidae: Tolmomyias) from the western Amazon basin. In: Remsen, J.V. (Ed.), Studies in Neotropical ornithology honoring Ted Parker (pp. 723-731). Ornithological Monographs 46. Washington D.C.: American Ornithologists Union. URL: https://sora.unm.edu/sites/default/files/journals/om/om048.pdf

Schulenberg, T.S., Stotz, D.F., Lane, D.F., O’Neill, J.P. \& Parker, T.A. (2007). Birds of Peru. London, UK: Helm Field Guides.

Sibley, D.A. (2014). The Sibley guide to birds, second edition. New York: Alfred A. Knopf.

Spencer, A. (2011). XC 81408 Swainson's Flycatcher, Myiarchus swainsoni. Xeno-Canto. URL: https://www.xeno-canto.org/81408.

Swarth, H.S. (1931). The avifauna of the Galapagos Islands. Occasional Papers of the California Academy of Science, 18, 1-299. URL: https://www.biodiversitylibrary.org/item/35726\#page/8/mode/1up

Swash, A. \& Still, R. (2000). Birds, mammals, and reptiles of the Galapagos Islands, an identification guide. New Haven, New Jersey: Yale University Press.

Taczanowski, L. \& Berlepsch, H. (1885). Troisième liste des oiseaux recueillis par M. Stolzmann dans l'Equadeur. Proceedings of the Zoological Society of London, 1877, 67-124. URL: https://www.biodiversitylibrary.org/item/91206\#page/167/mode/1up

Tellkamp, M. (2016, May 6). eBird checklist: https://ebird.org/view/checklist/S29500335 and eBird checklist: https://ebird.org/view/checklist/S40580001. eBird: an online database of bird distribution and abundance. Ithaca, New York. URL: https://ebird.org

Tellkamp, M. (2017, November 10). eBird checklist: https://ebird.org/view/checklist/S40423131. eBird: an online database of bird distribution and abundance. Ithaca, New York. URL: https://ebird.org

Vargas, H. (1996). What is happening with the avifauna of San Cristóbal? Noticias de Galápagos, 57, $23-24$. URL: http://aquaticcommons.org/6788/1/NG_57_1996_Vargas_Avifauna_San_Cristobal.pdf 
Wiedenfeld, D.A. (2006). Aves, the Galapagos Islands, Ecuador. Check List, 2, 1-27. DOI: 10.15560/2.2.1

Züchner, T. (1999). Species accounts of genus Coeligena, family Trochilidae. In: del Hoyo, J., Elliott, A. \& Sargatal, J. (Eds.), Handbook of the birds of the world, vol. 5: barn-owls to hummingbirds. (pp. 626-629). Barcelona, Spain: Lynx Edicions. 